\title{
1923-1960 Arası Süreçte Türkiye'de Cumhuriyet - Muhafazakârlık Geriliminin Mekânsal Yüzü
}

\section{Spatial Face of Struggle Between Republic-Conservatism in the Period of 1923-1960}

\author{
Gencay Serter ${ }^{1} \odot$
}

Öz

Devrimci ve modernist bir atlımla başlayan Cumhuriyet, kurulduğu andan itibaren muhafazakâr düşünce ile gerilimli bir ilişki içerisinde olmuştur. Türkiye'ye özgü koşullar içerisinde biçimlenen bu gerilim her iki düşünce sistematiğini farklı dönemlerde, o dönemin kendi özgün koşullarının dinamiğine göre biçimlendirmiştir. Cumhuriyet ve muhafazakârlık arasında süren mücadelede Cumhuriyetin kurulmasından, çok partili hayata geçişi içerisinde barındıran ve en kritik dönemlerden biri olarak belirginleşen 1923-1960 arası dönemin ilk yarısında (1923-1945) modernist dünya görüşünü hayata geçirmek için cumhuriyet, idari ve hukuki düzenlemelerin yanında, tüm bu atlımları gerçek anlamda gündelik yaşamda hâkim kılmak amacıyla mekânı devrimci bir tavırla şekillendirmiştir. 1945-1960 arası süreç ise cumhuriyet ideolojisi karşısında muhafazakâr ideolojinin güç kazanarak yeniden görünür hale gelmeye başladığı ve muhalefetini sürdürdüğü bir dönem olarak belirmiştir. Her iki dönem içerisinde de ideolojik açıdan mekân stratejik önemde olmuş ve her iki ideolojik kanadın birbirlerine karşı sürdürdükleri mücadelede etkin şekilde kullanılmıştr. Dolayısıyla günümüzde etkileri halen görülen cumhuriyet muhafazakârlık mücadelesinde, en kritik zaman aralığı olarak ortaya çıkan 1923-1960 arası dönem ideolojik ve pratik kırılmaların yaşandığı ve bunların mekân üzerinde izler bıraktığı bir dönem olmuştur. Bu kapsamda makalede, belirlenen zaman aralığı dâhilinde, muhafazakârlık-cumhuriyet mücadelesinin seyri ve bu mücadelede mekânın oynadığı stratejik rol analiz edilmeye çalışılmıştır.

\section{Anahtar Kelimeler}

Mekân, Muhafazakârlık, Cumhuriyet, Devrim, Modernizm

\begin{abstract}
The Republic, which was launched with a revolutionary and modernist initiative, has been in a tense relationship with the conservative thinking. This tension, formed under conditions peculiar to Turkey, has shaped both systems of thought in different periods with regard to the dynamics of the conditions peculiar to the period. During the struggle between republicanism and conservatism, at the first half of the period between 1923-1960, which includes the transition from establishment of the Republic to the multi-party system and comes to the fore as one of the most critical periods, in order to bring the modernist world view into action, beyond the administrative and legal regulations, the Republic shaped the space with a revolutionary attitude to make these initiatives dominant over the daily life. The duration between 1945-1960 has been a period which the conservative ideology became apparent again by gaining strength and continued its opposition. Space has been strategically important in ideological terms in both periods and it was actively used in the campaign of both ideological wings against each other. Accordingly, in the struggle between republicanism and conservatism, whose effects are still apparent, the 1923-1960 period, being the most critical time range, has been a period in which ideological and practical turning points occurred and left their traces on the space. In this context, the course of the struggle between conservatism and republicanism and the strategic role of the space in this struggle within the determined time period was tried to be analysed.
\end{abstract}

Keywords

Space, Conservatism, Republic, Revolution, Modernism

1 Sorumlu Yazar: Gencay Serter (Dr.), Şehir Plancısı, Tarım ve Orman Bakanlığı, DKMP Genel Müdürlüğü, Ankara, Türkiye. E-posta: sertergencay@yahoo.com ORCID: 0000-0001-9556-4068

Attf: Serter, G. (2020). 1923-1960 Arası süreçte Türkiye'de Cumhuriyet - Muhafazakârlık geriliminin mekânsal yüzü. SiYASAL: Journal of Political Sciences, 29(1), 113-141. http://doi.org/10.26650/siyasal.2020.29.1.0088 


\section{Extended Summary}

Conservatism is derived from Romanesque words "conservare" and "conservatismus" which means preserve as it is. The definition of conservatism involves; preserve, modest or prudent behaviour, traditional or conformist lifestyle, metathesiophobia or opposite of change but it is difficult to define conservatism as a political term. The main reason for this difficulty is that the definition is based upon the ideology which conservatism struggles with. The scope of conservatism is formed according to the opposing ideology, and its characteristics are different from fundamentalism. In this sense, the definition of conservatism varies depending upon the time and geography, according to the ideological pole which conservatism stands against. Moreover, in this scope, the relationship between conservatism and its counterpart is always dynamic and transitive. So, the definition and contents of conservatism, which appear in the historical scene of the French Revolution, changes according to the conditions of the time and the country where conservatism grows.

The relationship between conservatism and the Republic Revolution, created one of the most radical changes, involving contradictions and transitivities as well. 1923-1960 is the temporal border of this article. This period is one of the most significant chapters in Turkey's history because the relationship between conservatism and the republic was critical. But in this article the spatial reflection of the relationship between conservatism and the Republic Revolution has been chosen as a problematic.

The dialectic between the ideology and the space has been considered in the intellectual environment since the 1970s with Lefebvre's highlighted. In Lefebvre's thought, the space was defined both as a stage and an element used by ideologies for dominating themselves in everyday life as a substructure. As he highlighted in the sentence "what is the meaning of ideology without space" all ideologies aim to reshape the space in order to make their practices dominant over daily life.

Within this context, the Republic emerged with a modernist and revolutionary scoop, but it has been struggling against conservative ideology since it was established. The period 1923-1960 was critical in the conflict between the republic and conservatism, which involved the period from the establishment of the republic to a multi-party system. In the first half of the period (1923-1945), the republic shaped the space in the revolutionary manner, using administrative and legal regulations to get a grip on daily life. The Republic put its spatial implementations into practice in a wide range, from city planning scale to green area design scale, especially in the capital city of Ankara. Changes on a national and international scale and the economic inability of the young Republic prevented modernist practices from spreading over a wide geographical area.

Conservatism became visible and continued its opposition by using rural areas from 1945-1960. This period started with the de-renouncement of CHP's revolutionary attitude and was finalised with the selection of the Democrat Party. The Democrat Party, which defined itself as a democrat and conservative party, used space to make dominant it's ideology on daily life like in the previous period. Moreover, another difference from the early period of the Republic, the Democrat Party chose a liberal model for the economy. 
In addition to this, the Democrat Party used space as a field to accomplish the liberal model and at the same time conservatism to transform society.

As it can be seen, the period 1923-1960, was the most critical in the period of struggle between conservatism and the republic, which contains ideological and political clashes. In this article, the evolution of struggle between conservatism and the republic and the strategic role of the space in this struggle are analised for the period of 1923-1960. 


\section{3-1960 Arası Süreçte Türkiye'de Cumhuriyet - Muhafazakârlık Geriliminin Mekânsal Yüzü}

Cumhuriyet Devrimi 18. yy'dan itibaren Osmanlı'da başlayan modernleşme çabalarının devamı olarak ortaya çıkmıştır. Kabaca iki aşamalı olarak hayata geçirilen, III. Selim ve II. Mahmut dönemleriyle başlayan, Tanzimat ve Meşrutiyet dönemleri ile devam eden modernleşme süreçleri, toplumun belirli kesimlerini sınırlı bir amaç ve çerçeve içerisinde değiştirmeyi hedeflerken; Cumhuriyet, modernizmi daha keskin biçimde yorumlayarak sosyal hayatın ve bireyin, kökten ve toptan dönüşümünü hedeflemiştir. $\mathrm{Bu}$ anlamda Osmanlı'dan başlayarak devam eden sürecin sonucu olarak ortaya çıkan Cumhuriyet Devrimi; Türk modernleşme tarihinde bir kırılma noktasına işaret etmektedir. Bu durum Söğütlü tarafından "Türk modernleşmesinde ihya fikri, yerini inşa fikrine bırakmıştır" (Söğütlü, 2008, s. 46) biçiminde ifade edilmiştir.

Cumhuriyet'le gerçekleşen dönüşüm artık 18. yy'da başlayan modernleşme hareketleri gibi sembolik olarak belli konularda batı toplumları düzeyine ulaşmakla sınırlı kalmayıp, tam anlamıyla modern bir toplum yaratmayı ve yaşatmayı hedeflemiştir (Hanioğlu, 1981, s. 61). Bu doğrultuda Lefebvre'in "gönderme yaptığ 1 , tarif ettiği, söz dağarını ve bağlantılarını kullandığı, kodunu içerdiği bir mekân olmasa bir ideoloji nedir?” (Lefebvre, 2014, s. 13) ifadesinde altını çizdiği şekliyle mekân; İslam coğrafyası içerisinde en keskin dönüşümlerden birini yaratmış olan Cumhuriyet Devrimi'nin kendini var etmeye ve kalıcı hale getirmeye çalışırken kullandığı en önemli araç ve sahnelerden biri olmuştur. Bu ani değişim sürecine tepkiyle yaklaşan muhafazakârlığın da aynı şekilde yürüttüğü ideolojik mücadele içerisinde de mekân oldukça önemli bir yer tutmuştur.

Ancak Türkiye Cumhuriyeti'nin kuruluş aşamasında yetişmiş insan gücü ve ekonomik olanaklar anlamında kaynakların oldukça sınırlı olması ve yeni rejim hayata geçirilirken izlenen yanlış stratejiler nedeniyle, Cumhuriyet' in yaratmaya çalıştığı dönüşümün etkileri hem siyasal, hem de mekânsal anlamda sınırlı kalmıştır. Bu sebeple dönüştürülmesi hedeflenen eski yaşam anlayışının gündelik pratikleri, mekânsal temsilleri ile yeni rejimin oluşturmaya çalıştığ gündelik yaşama ait pratikler ve mekânsal temsillerin bir arada olduğu ikili bir görünüm ortaya çıkmıştır. Bu ikili görünüm Cumhuriyet tarihi boyunca devam etmiş ve iki ideolojik yapı arasındaki mücadelede yaşanan gerilimler ve kırılmalar süresince; mekân, hem bu süreçlerin izlerini barındıran, hem de bu mücadele içerisinde kullanılan başlıca araçlardan biri olagelmiştir.

Bu kapsamda 1923-1960 arası dönem, Cumhuriyet'in kuruluş yıllarını ve çok partili sisteme geçişle birlikte Demokrat Parti'nin iktidar dönemini içermesi açısından, keskin ideolojik dönüşümlerin yaşandığı ve bu ideolojik dönüşümlerin yarattığı kırılmaların, mekân üzerinde derin izler bıraktığı bir dönem olmuştur. Bu özelliğinden dolayı makale kapsamında çalışma aralığı olarak seçilen bu süreç, 1923-1945 ve 1945-1960 arası olmak üzere iki alt dönem dâhilinde incelenmiştir. Bu süreçler içerisinde yaşanan ideolojik kırılmaların ve süregiden mücadelelerin mekânı nasıl biçimlendirdiği ve mekânın bu mücadele içerisinde her iki ideolojik yapı tarafından ne şekilde kullanıldığı makalenin temel araştırma konusu olmuştur.

$\mathrm{Bu}$ çerçevede üç bölüm halinde kurgulanan makalenin birinci bölümünde muhafazakârlık, siyasal anlamda batıda ilk kez ortaya çıktığı dönemdeki değer ve 
kavramlar üzerinden tanımlanırken; çalışmanın sonraki bölümlerinde yürütülen tartışmalara yön vermesi açısından muhafazakârlığın barındırdığı değer ve kavramların ülkemiz özelinde nasıl somutlaştığ1 ortaya konulmaya çalışılmıştır. İdeolojik zeminde sürdürülen bu tartışmadan sonra, makalenin ikinci ve üçüncü bölümlerinde ise birbirinden çok farklı iki ideolojik anlayış çerçevesinde şekillenen 1923-1945 ve 1945-1960 arası dönemlere ait mekânsal pratiklerin, mekân-ideoloji diyalektiği çerçevesinde analizi yapılmaya çalışılmıştır.

\section{Muhafazakârlık ve Cumhuriyet Arasındaki Gerilimin İdeolojik Yüzü}

Köken olarak "korumak" ya da "olduğu gibi muhafaza etmek" anlamına gelen Latince'deki "conservare" ve "conservatismus" kelimelerinden türeyen "muhafazakâr" terimi mütevazı veya ihtiyatlı davranış, geleneksel hatta uyumcu bir hayat tarzı, değişim korkusu veya değişimin reddi gibi özellikle "muhafaza etmek" fiilinin belirttiği anlamlara gelebilmektedir (Heywood, 2010, s. 83). Siyasal bir tavir olarak muhafazakârlık ise esasen tanımı zor bir kavramdır. Özünde korumayı üstlendiği "durumu" oluşturan sosyal, ekonomik, yasal, dinsel, siyasal ve kültürel kurumların, geleneklerin çözülmesine yol açacak değiş(tir)melere karşı durmayı hedefleyen muhafazakarlık (Ergil, 1986, s. 113); felsefi bir düşünce ve siyasal bir yöneliş olarak mevcut düzenin değerine ve mümkün olduğunca korunması gerektiğine inanan bir düşünce biçimidir (Güler, 2009, s. 117). Bu anlamda muhafazakârlığı bir ideolojiden çok “düşünce üslubu ve düşünüş stili” (Manheim'dan akt. Bora, 1997, s. 8); her türlü ideolojiye eklemlenebilecek bir "tavır" ya da "ruh hali" (Çiğdem, 1997, s. 32) olarak tanımlayabilmek mümkündür.

Muhafazakârlığın ortaya koyduğu değerler en temelde muhafazakâr düşüncenin varsaydığı insan figürüne bağlı olarak biçimlenmiştir. İnsanı psikolojik ve ahlaki eksiklikleri ile resmeden muhafazakârlık (Heywood, 2010, s. 89; Ergil, 1986, s. 121; Burke, 2016, s. 90-92) Aydınlanmanın çizdiği insan figürünü soyut ve gerçekdışı bulmuştur (Nispet, 1990, s. 98). Muhafazakârlık insanı cennetten kovulan, günah işlemeye meyilli ve bu sebeplerden ötürü dizginlenmesi ve kontrol edilmesi gereken varlık olarak tanımlarken; ortaya koyduğu toplum kurgusu da bu insan figüründen yola çıkarak biçimlenmiştir. Bireyi en temelde günah işlemeye meyilli ve eksik olarak gören muhafazakârlık içerisinde birey silikleşirken; toplum, aile ve cemaat gibi kurumlar üzerinden şekillenmiştir. ${ }^{1} \mathrm{Bu}$ anlamda eksiklikleriyle resmedilen insanın, Tanrı'nın iradesine karşı gelir biçimde uzun süreli deneyimlerin neticesinde oluşan ve toplumun temelini oluşturan geleneksel kurum ve işleyişleri reddedip yerine yeni kurum ve işleyişleri koyma fikrine dayalı devrim düşüncesi, muhafazakârlığın kendini var ettiği mihenk taşı olmuştur.

İlk kez 1789 Fransız Devrimi'nden sonra tarih sahnesine çıkan ve toplumda meydana gelen altüst oluşlara bir tepki olarak biçimlenen muhafazakârlık, özünde değişime karşı bir direniş ve karşı koyma tavrını barındırmıştır. Muhafazakârlığın düşünce dünyasında kurucusu olarak kabul edilen Edmund Burke, devrim ruhunun mevcut durum ve zamanda menfaat yaratmak yerine eninde sonunda despotizmle sonuçlanacak bir fikir olduğunu ve mutlak şartla gelenekler neticesinde oluşmuş kanun ve kurumların ayakta tutulması

1 Muhafazakârlık bu yapıları hem (eksik ve günahkâr) bireyi kontrol edecek hem de bireyin eksikliklerini giderebileceği, ihtiyaç duyduğu güven ve aidiyet duygusunu sağlayabilecek yapılar olarak görmüştür (Serter, 2018, s. 24-27) 
gerektiğini ifade etmiştir (Burke, 2016, s. 50, 177-178). Bu tutum muhafazakâr düşüncenin belirsiz bir yapı-bozum süreci sonunda oluşacak gelecek fikrinden öte denenmiş olan geçmişe ve geleneğe referans vermeyi tercih eden yapısının temelini oluşturmuştur.

"Geleneğin muhafazakârlığın genel tematik bir nesnesi olması kaçınılmazdır. Çünkü muhafazakârlığın zamansal bilinci de, bugünü doğrudan ve adını koyarak öncelemese bile, geçmişten ve gelecekten uzaklaşmaya dayalıdır" (Çiğdem, 1997, s. 43). Ancak eski ve yeni kavramları üzerine diyalektik ilişkinin bir ürünü olan muhafazakârlık, tarihin derinliklerinde sabit bir döneme, tarza ve işleyişe referans veren, neredeyse donmuş bir zaman anlayışına sahip olan fundementalizmden (köktencilik) farklı olarak; tedrici ve kısmi değişimi savunmuştur. Kendini daha çok tarih sahnesinde ortaya çıkan kırılma noktaları üzerinden, yaşanan sürece tepki olarak biçimlendiren muhafazakârlı̆̆ın değişim fikrine ilişkin bakışını Edmund Burke şu şekilde açıklamıştır:

"Hepimiz, değişim kanununa boyun eğmek durumundayız. Değişim kanunu, tabiatın en güçlü kanunudur, belki de tabiatın varlığını devam ettirmesinin aracıdır. Bu yasa içinde bizim yapabileceğimiz, insan aklının yapabileceği tek şey, değişimin hissedilemeyecek şekilde, derece derece gerçekleşmesini sağlamak olabilir. Bu şekilde değişimden beklenen yararlar, dönüşümün sakıncaları yaşanmaksızın elde edilebilir” (Burke, 2005, s. 27).

Ani değişim karşıtllğııın karşısında tedrici değişimi savunan yapısı, muhafazakârllğın yenilik yaratan süreçlerle olan ilişkisini karmaşık hale getirmiştir. Tarihsel süreçte ilk kez modernizme tepki olarak doğan muhafazakârlık, sonrasında da modernizmin içsel yapısının gereği olarak ortaya çıkan tüm değişim süreçleri karşısında sürekli kendini yenilemiştir. $\mathrm{Bu}$ anlamda siyasal konumlanışını daima statusquoante (mevcut durumdan önceki durum) ölçütüne göre tanımlayan muhafazakârlık (Dubiel, 1998) "eski (kadim ve ezeli) ve yerleşik olanın, geleneksel ve kutsalın sürekliliğini modern koşullarda sağlamaya çalışmanın iradesine ve yeteneğine sahip" bir düşünce biçimi olmuştur (Bora, 1997, s. 6). Bu durum muhafazakârlık açısından paradoksal bir durum gibi görünse de esasen muhafazakârlığın modernizmden bağımsız tariflenemeyeceğinin bir ifadesidir. ${ }^{2}$

Türkiye özelinde muhafazakârlığı tanımlayıp, içeriğini belirleyebilmenin de bu anlamda yegâne yolu etkileşim içerisinde olduğu kırılma noktalarının tespiti ile mümkündür. Osmanlı'da 18. yy'da Islahat Hareketleri ile başlayan, Tanzimat ve Meşrutiyet dönemleri ile devam eden modernleşme sürecindeki yoğun batılılaşma hamlelerinden rahatsızlık duyan kitlelerin daha çok İslamcı bir refleksle oluşturdukları İslamcı muhafazakârlık Cumhuriyetle birlikte bambaşka bir çehreye bürünmüştür. 18. yy'da yaşanan gelişmelerin nihai aşaması olarak; epistomolojik kodunu saltanat, hilafet ve İslam'ın (üç rükn-u devlet) oluşturduğu Osmanlı Devleti'nin (İlknur meşe, 2006, s. 128) yerine kurulan Türkiye Cumhuriyeti, batı modernizminin değerleri doğrultusunda kökten bir altüst oluş içeren siyasal devrim olarak tarih sahnesindeki yerini alırken; muhafazakârlık, bu keskin dönüşümün karşısında Türkiye'ye özgü değerler çerçevesinde yeni bir içerikle kendi düşünsel altyapısını oluşturmuştur. Geçmişin yıkılarak geleceğin yapılması hedefi doğrultusunda modernlik düşüncesinin en belirgin uygulamalarına tanık olunan erken cumhuriyet dönemi, bu anlamda Türkiye'de muhafazakârlı̆̆ın yeniden inşa yılları olmuştur (İrem, 1997, s. 52).

2 Bu özelliğinden ötürü Dahrendorf muhafazakârlığı açıklamak için oldukça zihin açıcı şekilde "aydınlanmış muhafazakârlık" terimini kullanırken (Dahrendorf'tan akt. Bora, 1999, s. 54), Mannheim (1927) ise "rasyonelleşmiş gelenekçilik" tanımını kullanmıştır. 
Öncelikle ifade etmek gerekir ki Türkiye özelinde ortaya çıkan muhafazakârlığı batıdaki kadar net çizgilerle tanımlayabilmek mümkün değildir. Çünkü Türkiye'de muhafazakârlık, Avrupa' daki gibi felsefi ve siyasal alanda net biçimde Fransız Devrimi'ne karşı üretilen çerçevede karşı koyuş ve restorasyoncu bir tavrı Cumhuriyet Devrimi'ne karş1 göstermemiş, büyük oranda Cumhuriyet'in modernleşme projesine paralel biçimde gelişimini sürdürmüş ve hatta Türkiye Cumhuriyeti ideolojisinin kısmen parçası haline gelmiştir (Çiğdem, 2001 ve 1997, s. 44-58). Bu durum esasen hem muhafazakârlığın önceden de altı çizildiği üzere, modernite ile olan ve hatta onun üzerinden tanımlanmasını olanaklı kılan yapısal özelliğinden, hem de batı dışı ülkelerde yaşanan modernleşme süreçlerinin Türkiye özelinde ortaya çıkan görünümünden kaynaklanmıştır.

Muhafazakârlık konumunu sürekli mücadele halinde bulunduğu siyasal anlayışa göre tanımlayıp, biçimlendiren bir düşünce yapısına sahip olmuştur. Ancak batıda modernizm üzerinden tariflenen muhafazakârlığın modernite ile olan refakat ilişkisi, modernleşmeyi gecikerek yaşayan toplumlarda daha bariz şekilde görünür hale gelmiştir (Bora, 1999, s. 71). Bu ilişki hiçbir şekilde sürtünmesiz bir ilişki olmayıp, farklılıklara dayalı çatışmaları barındırdığı kadar, iç içe geçişkenlikleri de içeren bir yapıya sahip olmuştur. Örneğin Türk modernleşme çizgisini "muhafazakâr modernleşme" olarak tanımlayan ve Türk modernleşmesi ile muhafazakârlığın iç içe geçişkenliğinin altını çizen Bora (1999, s. 71), bu analizinin ayrılmaz bir parçası olarak Türkiye Cumhuriyeti'nin kurucu ideolojisinin "kuşkusuz kendisi hakkındaki bilinci itibariyle muhafazakârlığa ve kendini muhafazakâr olarak algılayan konumlara karşıttır; inkılapçıdır, ilericidir, cumhuriyetçidir, modernisttir” tespitinde bulunmuştur. Benzer şekilde Çiğdem (1997, s. 46) muhafazakârlığın modernite üzerinden tanımlanan bir düşünce yapısı olarak gerilimli refakat ilişkisinin altını çizdikten sonra, Türk muhafazakârlığının karşısına koyacağımız oluşumun, kaçınılmaz olarak cumhuriyet olduğunu belirtmiştir. Türk muhafazakârlığı açısından Cumhuriyet'in kuruluş yıllarında ortaya çıkan bu “politik iktidarsızlığın açtığı boşluk, daha sonraki dönemler[de] kültürel bir saldırganlıkla doldurulmaya çalışıl[mış] ve Türk muhafazakârlığının Cumhuriyet'e karşı tepkisi büyük oranda geleneklere referans veren kültürel bir form içerisinde biçimlenmiştir"3 (Çiğdem, 1997, s. 46, 47).

$\mathrm{Bu}$ anlamda Cumhuriyet'le birlikte yeniden şekillenen muhafazakârlığın dayandığı temel noktalardan biri kuşkusuz din olmuştur. Osmanlı Devleti’nin bakiyesi olarak kurulan Türkiye Cumhuriyeti İslamcılığı büyük oranda ideolojik kurgusunun dışında bırakırken; bu süreç muhafazakâr çevrelerce "Kemalist seçkinlerin... İslam dininin ve temsilcilerinin siyasal, toplumsal ve kültürel alanlardaki yetkilerini, güçlerini ve görünürlüklerini ortadan kaldırmakyoluyla dini bir tasavvur karşısında milliyetçi bir ideolojiyi etkin kılmak" biçiminde tanımlanmış (Ete, 2003, s. 48) ve halifeliğin kaldırılması başta olmak üzere yapılan bazı düzenlemeler, Türkiye Cumhuriyeti'nin İslam'la ve Müslüman dünya ile ilişkisini kesen (Ahmad, 1991, s. 6); zihinlerin İslami kavram ve değerlerden arındırılmasını hedefleyen

3 Bu çerçevede Cumhuriyet'in kuruluş döneminde hem muhafazakâr kanadın hem de yeni kurulan rejimin sözcülüğünü yapanlar, siyasetçilerden öte çarpıcı biçimde belirli dergilerde kendi ideolojik konumlarını dile getiren edebiyatç̧lar olmuştur. Pozitivizmi savunan ve aydınlanma düşüncesi ekseninde yeni rejimin sözcülüğünü yapan Şevket Süreyya Aydemir, Yakup Kadri Karaosmanoğlu, Recep Peker ve Nusret Köymen gibi isimler Kadro dergisi içerisinde toplanırken (Ertan, 1994, s. 88-92.); dini, paternalist ve geleneksel değerlerin savunulmasını öneren ve aynı zamanda liberal bir bakışla batının teknolojik gelişmelerinin alınmasını isteyen isimler Dergâh, Türk Düşüncesi ve Kültür Haftası gibi dergilerde görüşlerini ifade etmişlerdir (İrem, 1997, s. 54-56). 
(Özdalga 1998, s. 19-20; Shaw, 1977, s. 384) radikal hareketler olarak görülmüştür. ${ }^{4}$ Politik anlamda keskin şekilde laisizm politikası hayata geçirilirken; muhafazakarlık da Türkiye' de Türk İnkılabının ve modernleşmesinin en büyük aşırılığı olarak gördüğü laisizm politikasına karşılık, modernleşmeyi aşırılıklarından arındırma ve gelenekle barıştırma ilkesi doğrultusunda İslamcı göndermelerle kendini laisizme karşı bir tür kültürel restorasyon talebiyle ortaya koymaya çalışmış (Bora, 1997, s. 20, 21) ve muhafazakarlık yeni dönemde büyük oranda gelenekçi muhafazakârlık biçiminde şekillenmiştir. ${ }^{5}$

$\mathrm{Bu}$ restorasyoncu tavır içerisinde muhafazakâr kitleler Osmanlı düzeninin yıkılmasını kabul etseler de devrimin "radikal" uygulamalarını onaylamamışlardır. Bu kitleler "Kemalist inkılabın dünyevileştirme politikalarına karşı çıkmamakla beraber, dinin kişi ve toplum tarafından tamamen dışlanmaması gerektiğini” ileri sürmüşlerdir (İrem, 1997, s. 65). Bu çerçevede yeni rejime karşı geçmiş dönem olarak kodlanan Osmanlı’ya ve İslam'a referansla muhalefetlerini şekillendiren muhafazakâr çevreler, diğer yandan Cumhuriyet' in dünyevileştirme politikalarının yanında olmuşlar; kalkınma ve teknolojik gelişmeye yönelik hamleleri destekleyici bir tavır içerisinde bulunmuşlardır.

Türkiye'nin özgün koşulları gereğince karşıtlıkları ve içi içe geçişkenlikleri barındıran yeni rejimin ve gelenekçi muhafazakâr düşünce arasındaki gerilimli mücadele, yasal ve idari alanlarla birlikte mekân üzerinde de varlığını sürdürmüştür. Çünkü Lefebvre'in (2014, s. 205) "gerçekteyse hayatı değiştirmek için mekânı değiştirmek gerekir” önermesi uyarınca gündelik hayatı dönüştürerek kendi düşüncesini hâkim kılmayı hedefleyen her iki kutup, pratik hamlelerini mekân üzerinden gerçekleştirmiştir. Tüm bu eylemler, Cumhuriyet'in devrimci yüzü ile muhafazakâr kesim arasındaki ideolojik gerilimi mekânsal boyuta taşımış ve mekân üzerinden görünür kılmıştır.

\section{Muhafazakârlık ve Cumhuriyet Arasındaki Gerilimin Mekânsal Yüzü}

Lefebvre 'in "toplumsal yapı şehrin içinde yer alır, orada hissedilir olur, orada bir düzene işaret eder. Tersinden ifade edersek, şehir de toplumsal bütünün bir parçasıdır; kurumları, ideolojileri ... ortaya serer" (Lefebvre, 2015, s. 78) ifadesinde altını çizdiği üzere şehir basit şekilde bir sahne veya "üstyapı” unsuru olarak ele alınamayacak bir olgudur. Çünkü “mekân ve mekân politikası, toplumsal ilişkileri 'ifade eder’; fakat aynı zamanda onu etkiler de” (Lefebvre, 2013, s. 19).

4 Şapka Kanunu'nun kabul edildiği 25 Kasım 1925 günü yasaya tepki olarak Rize’de, Trabzon’un Of ilçesinde ve Giresun'da Nakşibendiler silahlı gösteri yapmışlar; Erzurum ve Maraş başta olmak üzere Çankırı, Çerkeş, Sivas ve Kayseri'de gösteri ve direniş hareketleri görülmüştür (Kırçak, 1989, s. 258; Akşin, 2012, s. 158). Benzer şekilde hilafetin kaldırılması Anadolu'nun birçok yerinde tepkiyle karşılanmış; hatta Silifke, Reşadiye, Bursa ve Adapazarı'nda isyanlar çıkmıştır. İstanbul'daki Tanin, Vatan, Tevhid-i Efkâr, Son Telgraf gibi gazetelerle birlikte, Adana'daki Toksöz gazetesi hilafetin kaldırılmasına karşı cephe almıştır (Kırçak, 1989, s. 242-243). Örneğin Ahmet Emin Yalman, 6 Kasım 1924 tarihli Vatan Gazetesi’nde kaleme aldığı yazısında Mustafa Kemal'i saltanat ve hilafete zorla el koyarak, yerine mutlakıyet yönetimini getirdiği gerekçesiyle suçlamıştır (Özek, 1964, s. 171).

5 Bu tutum Laroui’ye göre esas itibari ile Batı dışı ülkelerde görülen klasik bir görünümdür. Modernleşme süreçlerinin ve Batı uygarlığının meydan okuması karşısında kendisini sürekli bir tehdit altında gören bu ülkeler muhafazakârlığı genel itibariyle "otantik" uygarlığa ve öze dönerek diriliş çağrısına sahip gelenekçiliğin izinde ele almışlardır (Laroui, 1993, s. 114). Esas itibari ile Türkiye Cumhuriyeti’nin yaşadığı modernleşme süreci de aynı koşullara bağlı olarak Batı'daki örneklerinden oldukça farklı biçimde "muhafazakâr bir duruş ve düşünüş refakatinde" gelişmiştir (Bora, 1997: 16). Ziya Gökalp'le birlikte inşa edilecek olan Türk kültürünü yeni kurulan devletin harcı olarak gören ideoloji; Türk kültürü ile modernizmi harmanlamayı devleti ayakta tutacak formül olarak görmüş, Avrupa'daki gibi hümanizm ve pozitivizmin ağırlıklı olduğu bir çizgiden farklı olarak devletin öncelendiği ve kültürel yoruma dayalı bir çizgiyi benimsemiştir. 
Lefebvre ile birlikte bambaşka bir anlam ve içeriğe bürünen, hem bir alt yapı hem de bir üst yapı unsuru olarak ele alınan ve bu yöntem neticesinde felsefi bir çerçevenin temel bileşeni ve hatta belirleyeni haline gelen mekân bu çalışmada merkezi bir konumda bulunmaktadır. Bu kapsamda birbirinden çok farklı iki ideolojik ve ekonomik düzlemde gerçekleşen 1923-1945 ve 1945-1960 arası dönemlere ait mekânsal pratiklerin, mekânideoloji diyalektiği çerçevesinde analizi bu bölümde ortaya konulmaya çalışılmıştır.

\section{3-1945 Arası Dönem: Aydınlanma Projesi Olarak Cumhuriyet'in Yükselişi ve Gömülü Kalan Muhafazakârlık}

Cumhuriyet Devrimi, ideolojik anlamda Osmanlı mirası olarak gördügü ve batı karşısında düşünsel alanda geri kalmışlığın sebebi olarak konumlandırdığı muhafazakârlığa karşı yürüttüğü mücadeleyi gündelik hayatta hâkim ve sürekli kılmak amaciyla mekânı aktif olarak kullanmış; böylece "mekân" Cumhuriyet Devrimi ve muhafazakârlık arasındaki gerilimin arenası haline gelmiştir. Bu kapsamda bir yandan dinin, diğer yandan da iktidarın (saltanatın) şekillendirdiği toplum düzeninden (ümmet), modernleşmenin getirdiği toplum yapısına (millet) geçişi simgeleyen cumhuriyet ideolojisi, muhafazakârlığın kodları ile bezenmiş Osmanlı mekân kurgusunu unutturmaya ve yepyeni bir örüntüyü mekânda hâkim kılmaya çalışmıştır.

Cumhuriyet'in karşısında bambaşka bir model yaratmaya çalıştığ 1 Osmanlı İmparatorluğu dönemindeki mekân kurgusu, özü itibariyle muhafazakârlığa ilişkin kodların temsil edildiği bir yapıya sahip olmuştur. Bu mekânsal örüntü içerisinde öne çıan unsurlar, dini sembollerin mekândaki hâkimiyeti, kontrole dayalı toplumun yansıması olarak mahalle ölçeğinde somutlanan bölünmüş ve homojenize edilmiş yerleşim birimleri ve içe kapalı insan-toplum yapısının sonucu olarak mahremiyetin biçimlendirdiği kentsel yaşam kurgusu olmuştur.

Osmanlı kenti içerisinde dini sembollerin mekânsal anlamdaki dağılımı ele alındığında bu sembollerin bir hiyerarşi ve ağ biçiminde mekânda hâkimiyet kurdukları görülür. Bu tespiti destekler biçimde Kuban tarafından Osmanlı kenti, kendi içinde kademelenmesi olan bir düğümler sistemi olarak tanımlanmıştır. Bu sistem içerisindeki en büyük düğüm noktalarında büyük camiler ve külliyeler yer almıştır. Daha alt ölçekteki düğüm medrese, türbelerden oluşurken; en alt ölçekteki düğümde ise bir mescit veya çeşme bulunmaktadır (Kuban 1996'dan akt. Günay, 2005, s. 13). Tüm bu yapılar bir yandan mekânsal temsil, diğer yandan da gündelik hayatı dini kurallara göre şekillendiren yapılar olarak mekânda yer tutmuşlardır. Cami ve külliye yapıları en üst ölçekte bu görevi yerine getirirken daha küçük ölçekte tekkeler, bu hiyerarşik yapı içerisinde dinsel kuruluşlar olarak bugünkü derneklere benzer fonksiyonları yüklenerek Osmanlı toplumunun dine dayalı yaşam ve idare sisteminin "pekiştirici” birer parçası olmuşlardır (Mardin, 1991, s. 239). Bu kurgu Osmanlı'da padişahın iktidarını görünür ve her an güçlü şekilde hissedilir kılmak için mekânsal anlamda şehirlerden, köylere varana değin bütün ölçeklerde uyguladığı bir strateji olmuştur. ${ }^{6}$

6 Osmanlı kentlerinin bütününde bu kurguyu tespit etmek mümkündür. Kentlerden öte köylerde de uygulanan bu stratejinin etkisini Mardin'in şu şekilde ifade etmiştir: 'Padişah'ın İslamcı siyaseti, sembolik binalar inşa etme düşüncesi etrafında şekillenmiştir. Kendi camilerini yapamayacak kadar fakir olan köylerde, Sultan bir cami yaptırma programı tatbik ederek devletin varlığını yeniden teyit et[miştir]" (Mardin, 1991, s. 93). 
Bir yandan tek tek yapılar üzerinden mekânda hâkim kılınmaya çalışılan muhafazakâr ideoloji, diğer taraftan da gündelik hayatın süregiden ritmi üzerinden bu hâkimiyetini pekiştirme yolunu seçmiştir. Bu anlamda mahalle ve sokaklar iki önemli alan olarak belirginleşmişlerdir. Mardin, mahalleyi idari bir birimden daha çok kesif bir gemeinschaft ve sıradan bir Osmanlı vatandaşının normal ömrünün çoğunu içinde geçirdiği bir çevre olarak tanımlarken (Mardin, 1991, s. 72-73), Tekeli ise mahalleyi geleneksel yaşam tarzında yetişen, kent içi hareketliliği sınırlı, yöresel bağımlılığ fazla olan bireyler için ailesinden sonra gelen ilk topluluk olarak görmüştür (Tekeli, 2001, s. 11). Osmanlı'da birey ve toplum ölçekleri arasındaki stratejik önemi yüksek mekânsal ve sosyolojik birim olarak mahalle en temelde etnik ve dinsel (daha alt ölçekte de mezhepsel) ilişkilere göre belirlenmiş keskin bir ayrışmayla oluşmuştur ${ }^{7}$ (Faroqhi, 1997, s. 164). Bu ayrıştırma ve kontrol güdüsünü besler şekilde mahallenin çıkmaz sokaklarla ve iç mekân görünürlüğü çok düşük, iç avlulu ve yüksek duvarlarla çevrili evlerden kurulu fiziki yapısı bir yandan karşı cinslerin karşılaşmasını sınırlayacak, diğer taraftan da yabancıyı görünür kılan ve dişlayan bir kurguya sahip olmuştur. Mahremiyete dayalı kontrolü sağlayan sokaklar diğer taraftan da dini yapıları ve sarayı öne çıkaran unsurlar olarak kent yaşamının temel omurgasını oluşturmuşlardır. Tüm bu kurgu içerisinde Osmanlı'da çeşitliliğe, kendiliğindenliğe dayalı kamusal mekânın oluşumu kısıtlı kalmış ve şehirde süregiden gündelik yaşam sürekli dini ve idari yapıların temsilleriyle kontrol altında tutulmuştur (Kimyon ve Serter, 2015, s. 47).

Cumhuriyet'le birlikte ise Osmanlı'da öne çıkan mekânsal kurgu ve sembollerin karşısına yeni rejimin sembol ve kurgularını ortaya çıkaracak biçimde bambaşka bir mekânsal örüntü konulmaya çalışılmıştır. Bu amaç doğrultusunda Cumhuriyet, sahip olduğu kamucu ve modernizm yanlısı ideolojisini mekânda hayata geçirebilmek için planlamayı bir araç olarak keşfetmiş ve aktif biçimde kullanmıştır. Ancak açık şekilde ifade etmek gerekir ki Cumhuriyet, her ne kadar modernizmi ideolojisinin ana hatt1 olarak belirlese de, kent mekânına ilişkin yürüttüğü pratiklerde modernizmin yıkıcı yüzünü benimsememiş, eskiyi koruyup, yeniyi kurmak biçiminde özetleyebileceğimiz bir mekânsal strateji doğrultusunda pratiklerini hayata geçirmiştir. Bu tavrı esasen Cumhuriyet'in içerisinde muhafazakar bir damarı barındıran modernist tutumunun mekana yansıyan görünümü olarak yorumlamak mümkündür. Bu politikanın makro ölçekte tezahürü İstanbul'a karşı Ankara'nın ön plana çıkarılması olurken, kent ölçeğinde yürütülen çalışmalarda da eski kent dokusunun korunması, yeni rejim ideolojisinin ifade edileceği düzenlemelerin ise yeni alanlar üzerinde inşa edilmesi biçiminde olmuştur. $\mathrm{Bu}$ çerçevede yeni rejimin kendine başkent olarak seçtiği Ankara'da bile eski kente yönelik yıkıcı müdahalelerde bulunulmamış; eski ve yeni kent bölgelerinin bütünlüklü ve ilişkili biçimde ele alındığı kurgu dâhilinde; rejim kendi kurgusunu yeni kent içerisinde katıksız biçimde uygulamaya koyarken, eski kent dokusunu büyük oranda

7 Örneğin 1830'larda Ankara'daki 107 mahalleden 57 tanesi Müslüman, 27 mahalle gayrimüslimlerden oluşmuştur. Karışık nüfusa sahip olan mahalle sayısı sadece 23'tür. Hatta gayrimüslim mahalleler de etnik kökene göre kendi içlerinde ayrışmışlardır (Georgon, 1996, s. 104). Bu doğrultuda 19. yüzyıl Ankara'sında mahallelerin dini açıdan ayrışmışlıklarını ve demografik yapılarını gösteren bir başka çalışma için bkz. Özdemir R., (1986), 19. Yüzyılın İlk Yarısında Ankara, Kültür ve Turizm Bakanlığı Yayınları, Gazye Mat. San. ve Tic. A.Ş. Ankara. 
korumuştur. ${ }^{8}$ Ortaya çıkan bu ikili yapıyı, 1928 yılında Ankara'daki deneyimlerini kaleme alan Eugene Pitard'ın şu alıntısı çarpıcı biçimde ortaya koymaktadır:

"Eski Ankara'nın sokaklarında dolaşmak pek keyifli oluyor. Bazı cumbalı Türk evleri birbirine o kadar yakındır ki semayı görmek güçtür. Birdenbire bir ağaca, bir çeşmeye tesadüf edilir. Siyah elbiseli bir kadın elinde bir desti ile geçer. Kalenin en yüksek kısmında kireçle sıvanmış evler vardır ki, güneşin son şuaları üzerlerinde temerküz eder. Ankara karaltı içinde dalmağa başladığı, ova, yer yer küçük bir derenin gümüş çizgisinin yırttığı sislerle kaplandığı vakit bile, güneşin son şualarını üzerlerine çeken bu evler eski şehre son bir aydınlık verirler...Harabeler arasından geçerek Yenişehir'e, geniş caddelere doğru iniyoruz. Orada, garba has olan faaliyet ve hareketi, istasyondan gelen otobüsleri, zengin dükkânları, yataklı vagon idaresini, sinemayı buluyoruz. Bir çeyrek saat içinde iki medeniyeti ve iki ruhi haleti birbirine bağlayan merhaleleri aştık" (Pitard'dan akt. Cengizkan, 2004, s.57).

$\mathrm{Bu}$ temel strateji doğrultusunda kentlerde batılı tarzda modern yaşama ilişkin binalar, heykeller, parklar vb. öne çıkarken; ulaşım artık dar sokaklar ve çıkmaz sokaklar üzerinden değil, geniş bulvarlar ve açık yeşil alanlar üzerinden kurgulanmaya başlanmıştır ${ }^{9}$ (Bkz. Fotoğraf 1). Bulvarlar, meydanlar, açık yeşil alanlar Osmanlı kent mekânının aksine içe kapanmayı değil, kamusallığı ve dayanışmayı artırmak ve bu doğrultuda da insanı özgür kılmayı hedefleyen mekânsal kurgunun parçaları olarak kent mekânındaki yerlerini almışlardır (Bkz. Fotoğraf 2).

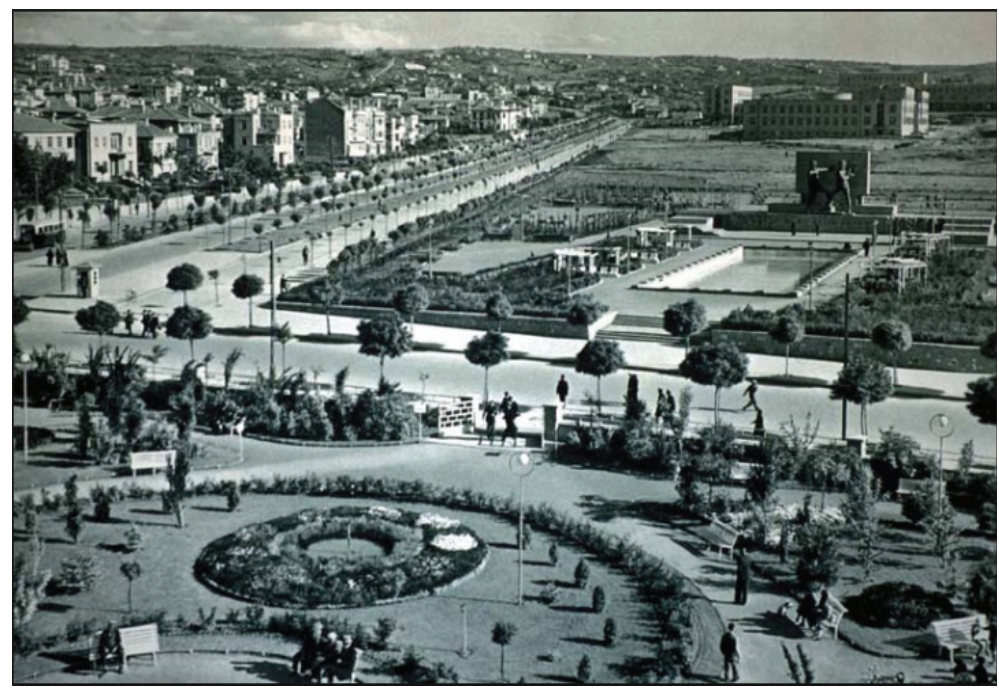

Fotoğraf 1. Ankara Kenti Atatürk Bulvarı ve Güvenpark (Kaynak: https://www.google.com.tr, (04.02.2017))

8 Bu tutum Ankara'daki ilk mekânsal düzenlemelere rehberlik etmiş olan Lörcher Planı'ndan itibaren devam etmiş; Ankara'nın gelişimini yönlendirecek planı elde etmek için düzenlenen uluslararası yarışmada yıkıcı bir biçimde şehri silip süpüren Leon Jausseley’in planı yerine daha mütevazı ve eski kenti korumaya yönelik çözümler geliştiren Jahnsen'in planı seçilmiştir (Tankut, 1990, s. 55).

9 Osmanlı döneminde yeşil alan olarak kullanılan mesire alanları dahi muhafazakâr yaşamın kodları üzerinden katı bir kontrol ve dışlama üzerine kuruludur. Osmanlı kayıtlarında birçok mesire alanına ilişkin giriş çıkışların yasaklandığı, özellikle kadınların mesire alanlarındaki davranışlarını sınırlamaya yönelik düzenlemelere rastlamak mümkündür. Bu konudaki örnekleri içeren bir makale için (Bkz. Yazıcı, 1999, s. 253-258). 


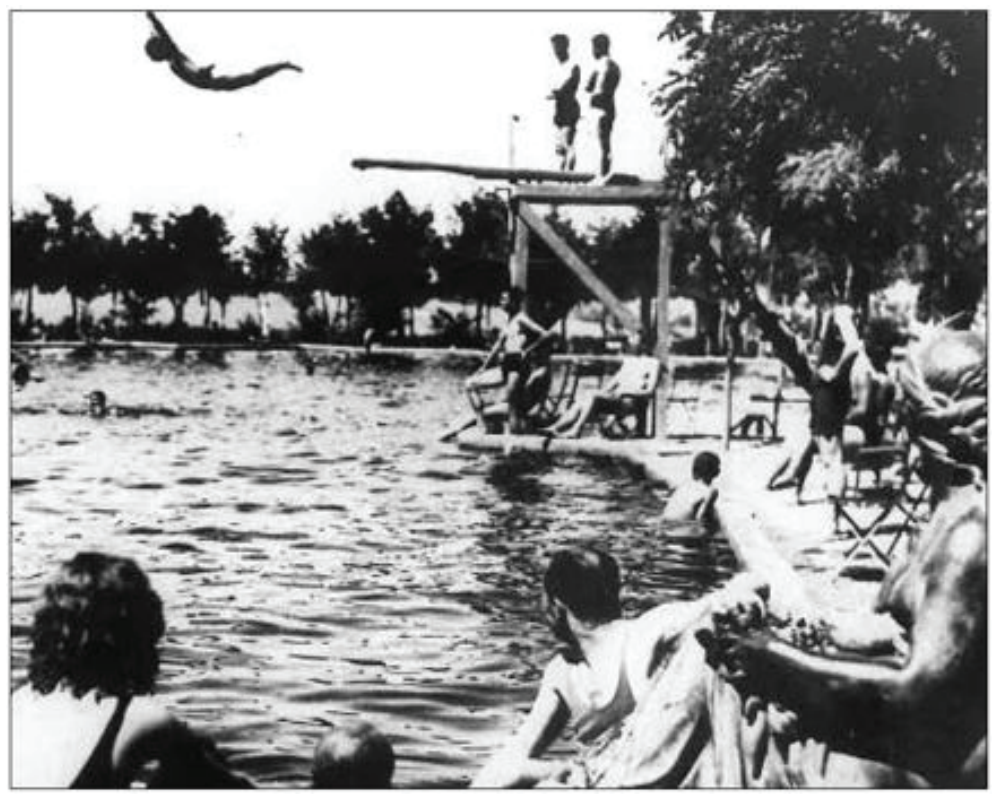

Fotoğraf 2. Atatürk Orman Çiftliği Karadeniz Havuzu

(Kaynak: http://haber.sol.org.tr/kent-gundemleri/devlet-ciftligindenrant-odagina-ataturk-ormanciftligi-haberi-48135, (08.11.2011)).

$\mathrm{Bu}$ tutum insanı güvenilmez ve denetim altında tutulması gereken bir varlık olarak gören muhafazakârlığın aksine, insanı önceleyen ve hâkim kılan bir düşünce sisteminin mekândaki ve gündelik yaşamdaki yansıması olarak görülmelidir. "Belirli bir yöreye bağlılığ1 azalmış, yer değiştirebilen, çok uzaklardaki değişmelerden haberdar olan, yani akışkanlığı artmış" (Tekeli, 2001, s. 11) modern birey için algılanan mekânın ölçeği büyümüş, homojen ve kontrole dayalı mekân kurgusu içerisinde çıkmaz sokak ve mahallenin mekândaki hâkimiyeti azalmıştır. Bu kurgu özellikle kadını içe kapanmaya zorlayan, yabancıyı dışlayan mekânsal kodlardan köklü bir kopuşu ifade etmektedir. Artık geniş bulvarlar ve yeşil alanlar herhangi bir şekilde mahalle bazında bir birlikteliği değil, farklılıkları ve özellikle kadının da içerisinde mutlak şartla bulunduğu bir sosyal hayat organizasyonunu hedeflemiştir. ${ }^{10}$

Mekân kurgusuna ilişkin bu kopuş öylesine keskindir ki, insanın günahkâr ve yetersizliği varsayımından yükselen muhafazakârlığın keskin kanadını temsil eden İslamcı muhafazakârlığın resim ve heykeli yasaklayan duruşuna karşılık; ${ }^{11}$ yeni

$10 \mathrm{Bu}$ noktada Mardin özellikle kadın hakları üzerine Atatürk’ün yaptığı hamleleri şu şekilde özetlemiştir: “Atatürk'ün kadın haklarının tesisi için yaptı̆̆ı hamle, ona mahalle ethos'unun en boğucu ve karanlık yönü gibi görünen șeyi, yani günlük hayatın sıradanlığı içinde kadın ve erkek ilişkilerinde görülen kısıtlamaları yerle bir etmek için girişilmiş kesif bir çaba olarak kavramlaştırılabilir” (Mardin, 1991, s. 76).

11 Resim ve heykel sanatına ilişkin Muhyiddin İbn Arabi’nin görüşü şu şekildedir: “...ruh sahibi olan bir varlığın resmini yapmaktan sakın. Kuşkusuz bu iş insanların gözünde önemsiz, basit bir iștir. Ressamlar/ heykeltıraşlar (el-musavvirun) kıyamet gününde en şiddetli azaba çarptırılacak insanlardır. Kıyamet günü 
Cumhuriyet, insanı ve aklı önceleyen, yücelten tavrıyla kentin en görünür ve en çok ziyaret edilen yerlerini anıtsal ölçekteki heykellerle ve havuzlarla donatmıştır. Bu anlamda Güvenpark’taki Emniyet Anıtı (Bkz. Fotoğraf 3) çarpıcı bir örnektir. Avusturyalı mimar C. Holzmeister tarafından başlanan, Joseph Thorak tarafından 1935 yılında bitirilen abide, o zamana kadar bu coğrafyanın gördüğü en büyük anıtsal heykel olmuştur. Resim ve heykel yapımının yasaklandığı bir inanç sistemi ve mekânsal coğrafya içerisinde esasen bu abide ciddi bir dönüşümün sembolü olmuştur. ${ }^{12}$

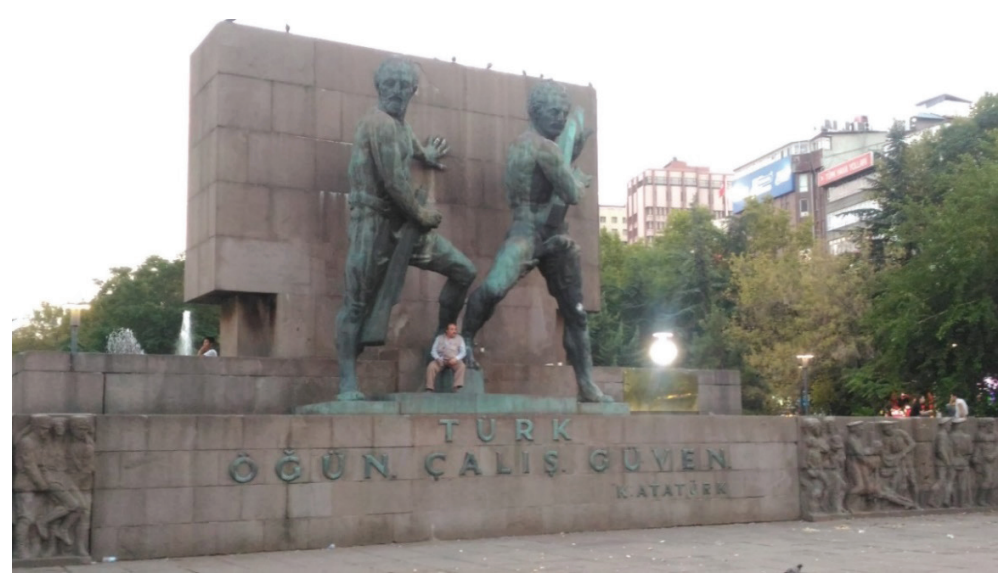

Fotoğraf 3. Güvenpark Emniyet Anitı

(Kaynak: Serter, 2017)

Görüleceği üzere Cumhuriyet'in kurucu kadrosunun modernleşme çabası sadece hukuki ve idari boyutta kalmamıştır. Gündelik hayatı değiştirmek ve inkılapları kalıcı kılmak için mekân etkili şekilde ancak sınırlı bir coğrafya içerisinde kullanılmıştır. Bu anlamda Osmanlı'yı simgeleyen ve hatırlatan İstanbul'a karşı yeni Cumhuriyet' in başkenti Ankara, en görünür ve kapsamlı mekânsal müdahalelerin yapıldığı şehir olmuştur. Bu duruma ilişkin tutumu Atatürk "Hiç kuşku etmemelidir ki, Anadolu ortasında hızla meydana getirilecek çağdaş ve imar görmüş bir Ankara, yüzyıllarca ihmale edilmiş (mühmel) olan Türk Vatanı için başlı başına bir uygarlık özeği, Türk Devleti için pek önemli bir dayanak olacaktır” biçiminde ortaya koymuştur (Geray, 2008, s. 11).

Cumhuriyet rejimi için bu seçim ümmetten millete dönüşümün, ulusal birliğin, oluşturulmaya çalışılan yeni kültür doğrultusunda toplumu yeniden yaratma çabasının ve insana güvenin mekânsal ifadesi olmuştur. Yeni başkent Hermann Jansen tarafindan çağdaşı olan modern batılı metropollerin kurgusuna benzer şekilde planlanırken; başkent

ressam ve heykeltıraşa, "yarattı̆̆ın şeyi haydi dirilt ya da ona can ver" denilir. Oysa o onu ne diriltebilir ne de can verebilir" (Muhyiddin İbn Arabi, 2009, s. 57).

12 Güvenpark Anıtı boyut olarak büyüklüğünden öte ön yüzünde Cumhuriyet'in öne çıkardığı insan figürünü çarpıcı şekilde ortaya çıkarmak için çıplaklığı kullanması açısından dikkat çekicidir. Bu figürlerin çıplaklığı, cinsel organlarının görünürlüğü o dönemde tepkiyle karşılanmıştır (Ertuna, 2004). Bu durum o zamanın dünyasında Cumhuriyet'in dönüştürmeye çalıştığı toplum yapısı ekseninde İslamcı muhafazakârlık ve Cumhuriyet arasındaki gerilimi kent mekânındaki bir heykel üzerinden ortaya sermesi açısından çarpıcı ve net bir örnektir. 
Ankara artık Cumhuriyeti temsil eden yap1 ve kurgularla, cumhuriyet fikrini sürekli diri tutacak heykellerle, modern yaşamın en belirgin şekilde hissettirilebileceği ve batı metropollerine benzer; ancak batı metropollerindeki örneklerini bile kat be kat aşan yeşil alan kurgularıyla, ${ }^{13}$ modern yaşamı temsil eden bir başkent haline gelmiştir. Bu anlamda kentsel mekânın ve kentlinin örgütlenmesi bağlamında Ankara, modern Türk kentlisinin doğum yeri, modernleşme serüveninin laboratuvarı olmuştur (Kılınç, 2009, s.135).

Mekân düzenlemeleri ve semboller üzerinden yürütülen bu mücadelenin yanında Ankara ekonomik anlamda da bir mücadelenin ve dönüşümün merkezi olmuştur. Şengül'ün “Ulus Devletin Kentleşmesi” olarak tanımladığı 1923-1950 dönemi, ulus devletin oluşum sürecinde gerçekleşen ve başını devletin çektiği, imparatorluk temelli toprak düzeninden, ulus devlet merkezli bir düzene geçişi içermiştir (Şengül, 2009, s. 103). Bu dönüşüm içerisinde devlet yatırımları ekonominin itici gücü olurken, bu dönemde yatırımlar Başkent Ankara'yla birlikte Anadolu'ya mümkün olduğunca eşit dağıtılmaya çalışılmış ${ }^{14}$ ve Anadolu'yu önceleyen bir ulaşım ağı yaratılmıştır (Şengül, 2009, s. 114, 115). Yeni kurulan Cumhuriyet en önemli sorunsallarından birini bölgesel gelişmişlik farklılığını azaltmak ve İstanbul'un baskın kent (primate city) olmasını engellemek üzerine kurmuş olmasına rağmen bunda kısmi oranda başarılı olabilmiştir.

$\mathrm{Bu}$ durumun en önemli sebebi elbette ekonomik kaynakların kısıtlılığı olmuştur. Yeni kurulan Cumhuriyet ağır savaş koşullarından çıtığı için ekonomik anlamdaki yetersizliklerden dolayı sanayileşme hamlesini hemen gerçekleştirememiş ve kırsal karakterli nüfus yoğunluğu uzun yıllar devam etmiştir. Bu kısıtlı koşullar içerisinde Cumhuriyet' in yeni yüzünü ve yeni yaşam biçimini temsil edecek mekânsal düzenlemeler Ankara başta olmak üzere belirli birkaç şehirde hayata geçirilebilmiş; kırsal kesim üzerine Cumhuriyet'in hem mekânsal, hem de siyasi ve idari dönüşümlerinin etkisi çok sınırlı kalmıştır. ${ }^{15} \mathrm{Bu}$ durum genç Cumhuriyet içerisinde birbirinden başka bir zaman ve mekân kompozisyonunda yaşayan birbirine zıt iki farklı dünya yaratmıştır.

Coğrafya üzerinde giderilemeyen bu gelişmişlik farkı Cumhuriyet ile muhafazakârlık arasında ontolojik olarak var olan gerilimi sürekli olarak besleyen bir ikilik yaratmıştır. Çünkü Black'in altını çizdiği üzere ulusal pazarın kurulması ve buna yönelik işleyişsin kurgulanması uzun erimli ve zor bir sürecin sonunda gerçekleşebilmektedir. Ancak bu değişimlerin içerisinde gerçekleştiği toplumun düşünce, inanç ve değerlerinin dönüşümü ise ekonomik dönüşümlerden çok daha uzun süreli ve zor bir süreci gerektirebilmektedir (Black, 1986, s. 67). Tekeli tarafından "modernleşme açığı” olarak kavramsallaştırılan bu durum gelişmiş kapitalist ülkeler dışındaki çevre ülkelerin karşı karşıya kaldıkları sosyolojik bir durum olarak ortaya konulmuştur. Kapitalizmin işleyişinin yarattığ

13 Ankara'nın en büyük yeşil alanı olan Atatürk Orman Çiftliği kuruluşundan itibaren en büyük sınırlarına ulaştığında 55.000 dönüm büyüklüğünde olmuştur. Londra'daki Hyde Park 1500 dönüm, New York şehrinde bulunan Central Park ise 3382 dönüm büyüklüğündedir.

14 Nazilli, Kırıkkale ve Ereğli gibi küçük yerleşimler bu dönemde en hızlı büyüme oranlarını yakalamışlardır. Bu kentlerin ilk on yıllık dönemindeki nüfus büyüme hızları \% 5 iken İzmir ve İstanbul gibi büyük kentler (Ankara hariç) nüfus artışları \% 1,4 civarında kalmıştır. 1927 yılında nüfusu 50.000'i aşan 5 kent varken, 1950 yılında bu sayı 11'e ulaşmıştır. Eklenen bu 6 kentin tamamı gelişmiş Marmara bölgesinin dışındaki iller olmuştur (Şengül, 2009, s. 115).

15 Örneğin İsviçre Medeni Kanunu esas alınarak hazırlanan Medeni Kanun kırsal kesimin sosyal yapısına pek de uymamış; bu sebeple kırsal kesimdeki evliliklerin önemli bir kısmı gerektiği gibi tescil edilememiştir (Mardin, 1991, s. 131). 
yayılmacı etkinin sınırlı düzeyde kaldığı durumlarda modernizmi uygulama misyonuna sahip yönetici elitler "sosyal mühendislik" uygulamaları ile tepedenci diye adlandırılan müdahaleler gerçekleştirmek zorunda kalmışlardır (Tekeli, 2001, s. 12-13). Ancak bu uygulamalar her koşulda kapitalist batı dünyası ile karşılaştırıldığında veya modernleşme projesinin uygulandığı ülkenin kendi sınırları içerisinde, ekonomik gelişme düzeyleri anlamında bir "modernleşme açığı" ortaya çıkarmıştır. Kültürel dönüşümün altyapısının kurulamamasından kaynaklı olarak Cumhuriyet'in yeniliklerinden faydalanan sınırlı sayıdaki kesim ile bu yeniliklerden hiçbir pay alamayıp, kentli kesimle arasındaki gelişmişlik farkı sürekli derinleşen kırsal kesim arasındaki bu gelişmişlik farkı, kırsal kesimin kültürel üst yapısını oluşturan muhafazakârlık ile cumhuriyet ideolojisi arasındaki gerilimi besleyen ve sürekli kılan bir yapıyı ortaya çıkarmıştır. Bu kapsamda Mardin'in tespitine göre “Anadolu'nun fakirliği dini etkinliklere de yansı[mıştır]. Cumhuriyet' in bu taşra yerleşimlere sızmada eksik kalması yetersiz kaynakların sonucuydu ve bu 1940'lara kadar sür[müştür]. Böylece yerel nüfus kültürel ekolojilerin sertliğini aşmanın yolunu dinde bul[muştur]” (Mardin, 1991, s. 221).

Cumhuriyet'in ilk yıllarından itibaren toplumun toptan modernleştirilmesi sürecinde kültürel cephede sürdürülen mücadele ile ekonomik, sosyal ve politik alanda sürdürülen mücadelenin eşgüdüm halinde sürdürülememesi neticesinde, hedeflenen dönüşüm coğrafyanın büyük ekseriyetinde başarılı olamamış; ${ }^{16}$ muhafazakâr düşünce yapısı, Cumhuriyetin modernite projesi karşısında bir kutup olarak yer almıştır. En nihayetinde bu iki kutuplu yapı, mekânsal alandaki gelişmişlik farklılıkları neticesinde pekişen ve mekânın kullanım dilinden ve amacından kaynaklanan bir gerilim yaratmıştır. Cumhuriyet'in ilk yıllarındaki ikili yapı çerçevesinde süregelen gerilim, kırsal kesimden büyükşehirlere başlayan göç hareketi ile mecra değiştirmiş ve daha öncesinde kırsal alanda gömülü kalan muhafazakârlık büyükşsehirlerin içerisinde hissedilir hale gelmiştir.

\section{5-1960 Arası Dönem: Liberal Ekonomik Dönüşüm Ve Muhafazakârlığın Kentleşmesi}

Türkiye tarihindeki en önemli dönüşümlerden biri olarak çok partili hayata geçiş; ekonomide liberalizmin yükselişe geçtiği, siyaseten de muhafazakârlığın etkinliğini artırdığı bir süreci başlatmıştır. Esasen bu dönüşüm süreci içte olduğu kadar dışta da gerçekleşen bir takım gelişmelerin neticesinde ortaya çıkmıştır. İki kutuplu dünyanın Türkiye'yi batı bloğuna yaklaşmaya mecbur bırakması; diğer yandan çok partili sisteme geçiş sürecinin başlaması ve ekonomik yetersizliklerin halkta yarattığı memnuniyetsizlik, CHP'nin önceki dönem kadar rahatlıkla iktidarını sürdürmesini olanaksız hale getirmiştir. İçte ve dışta ortaya çıkan ekonomik ve siyasal ortam CHP'yi devletin ana aktör olduğu ekonomi modelinden liberalizme geçişe zorlarken, siyasal anlamda da muhafazakâr kitlelere karşı daha uzlaşmacı bir siyaset tarzını benimsemeye zorlamıştır.

$16 \mathrm{Bu}$ durum Cumhuriyet aydınlanmasının edebiyat dünyasındaki en etkili savunucularından Yakup Kadri Karaosmanoğlu tarafından biraz da öfkeyle şu şekilde dile getirilmiştir: "Yıllar yılıdır, geceli gündüzlü haykırıp durduğumuz inkılap kelimesinin daha (i) harfi bile buraya aksedememiş. Kabahat kimde? Halkta mı? Hayır, bin kere hayır; kabahat, bir inkılabın plansız, teşkilatsız ve tekniksiz yapılabileceği hayaline kapılanlardadır. İki üç maddelik bir kanun, valiye, polise, jandarmaya birer emir...Her şeyi olmuş bitmiş farz ediyoruz; bu kanunların, bu emirlerin kafanın içi şöyle dursun hatta dışını bile değiştiremediğini görmek istemiyoruz" (Karaosmanoğlu, 1987, s. 109). 
Türkiye Cumhuriyeti, 1947'de Uluslararası Para Fonu (IMF) ve Dünya Bankası'na katılımla liberal ekonomik sisteme en üst ölçekte entegrasyonunu başlatıp, ABD'den alınan maddi yardımlar ile bu süreci perçinlerken; diğer taraftan da siyasal alanda muhafazakâr değerlere yönelen bir takım pratikleri hayata geçirmeye çabalamıştır. $\mathrm{Bu}$ yönelişin ilk örneği olarak, "laikliğin tartışılmaya başlandığı 7. Cumhuriyet Halk Partisi Kongresi'nde (1947) dinin ihmal edilmiş bir toplumsal pekiştirici olduğu ilkesi çok açık olarak ortaya sürülmüş" (Mardin, 1991, s. 32) ve "[d]inin...siyasi, manipülatif, merkezden yönlendirilen boyutlarının siyasi tercihleri etkilemek için bir ideoloji olarak kullan[1ldığ1]" (Mardin, 1991, s. 222) süreç başlamıştır. ${ }^{17}$

$\mathrm{Bu}$ dönemde muhafazakârlık lehine gerçekleşen dönüşümün neticesi olarak 1949 yılında ilkokullarda seçmeli din dersleri verilmeye başlanmış, aynı yıl Ankara'da İlahiyat Fakültesi'nin kurulmasını öngören bir kanun kabul edilmiş, 1949 yılında türbeler yeniden ziyarete açılmış ve 1950'de imam-hatip kursları okullara dönüştürülürken, sadece Milli Eğitim'e bağlı okullarda değil, izin almak koşuluyla bağımsız din bilgisi dershanelerinin ve din seminerlerinin açılmasına izin verilmiştir (Yaşlı, 2014, s. 70-73). 1940'ların sonlarında dini politikaların liberalleştirilmesinden sonra sosyolojik anlamda meydana gelen bir diğer önemli gelişme ise çok geniş manada tarikat olarak afişe edilen dini grupların tekrar ortaya çıkması olmuştur (Mardin, 1991, s. 100, 124).

Oluşan bu ortam içerisinde Demokrat Parti, CHP içerisinde bulunan liberal anlayışı ağır basan kişiler tarafından kurulmuş bir parti olarak siyaset sahnesine girmiştir. ${ }^{18}$ Siyasal olarak bu yeni oluşum, CHP'nin kuruluş aşamasındaki devletçi-devrimci ideolojisine karşıt olarak liberal-evrimci bir ideolojiye sahip olmuştur (Kocabaş, 2011, s. 166). Modernizmi muhafazakar bir eleştiriyle yorumlayan Demokrat Parti Cumhuriyet'in kalkınma vizyonunu benimseyip, bu vizyon çerçevesinde devletçi bir model yerine liberal ekonominin gereklerini sahiplenirken; Cumhuriyet'e eleştirisini ise daha çok İslam ve Osmanlı dönemine referanslar içeren gelenekçi bir tavırla sürdürmüştür. $\mathrm{Bu}$ anlamda tek parti döneminde kendini dışlanmış hisseden muhafazakâr kitlelerin arzularına cevap verecek biçimde Demokrat Parti gelenekçi muhafazakârlığın temsilcisi olmuştur.

Devrim fikrine ontolojik bir karşı duruşu içerisinde barındıran muhafazakârlığın temsilcisi olarak Demokrat Parti, benimsediği gelenekçi muhafazakâr yapı içerisinde sosyal hayatta köklü değişimler yaratmış Cumhuriyet'in; kuruluş aşamasındaki

17 Tekeli, yaşanan bu dönüşümü esas itibari ile geç aydınlanan ülkelerde yönetici aydın kitlesi ile geniş halk kitleleri arasında yaşanan gerilimin kaçınılmaz sonucu olarak görmüştür. Tekeli'ye göre aydınlanma ideolojisini benimseyen kitleler ahlaki olarak taşıdıkları misyon gereği, aydınlanmayı topluma yayma hedefiyle geniş halk kitlelerine doğru dönüştürücü politikaları uygulamaya koyarlar. Ancak arzulanan bu devrimci dönüşümün gerçekleşmesi için "iktidarı" elde etmek ve elde ettikten sonra da muhafaza etmek stratejik bir zorunluluk olarak ortaya çıkar. Geç aydınlanan ülkelerde büyük oranda azınlık iktidarı olarak ele geçirilen siyasal güç, uzun vadede sürekli bir meşruiyet sorunuyla karşıllaşır. Çünkü aydın azınlığın iktidarı, sürekli olarak, iktidarın çoğunluğa dayanması ölçütüne göre eleştirilir ve halkın çoğunluğuna karşı iktidar olmak suçlamasına muhatap kalır. Bu durum aydınlanmayı yaygınlaştırma misyonuna sahip kitleler için baş edilmesi zor bir ikilemdir. Bu ikilemi aşmak hedefi ortaya konulduğu andan itibaren popülizmin ortaya çıkması; popülizme düşüldükçe de tarihi misyon olarak aydınlanmanın toplumda yaygınlaştırılması hedefinden uzaklaşılacağı kesindir (Tekeli, 2001, s. 36, 37).

$18 \mathrm{Bu}$ dönem CHP'nin karşısına çıkan tek parti elbette Demokrat Parti değildir. İstanbul'da 1946 yılında İslam Koruma Partisi, 1947 yılında Ankara'da Türk Muhafazakâr Partisi ve 1948 yılında Ankara'da Millet Partisi, muhafazakâr kimliği ağır basan partiler olarak kurulmuşlardır. Ancak dönemin koşulları gereği ya kapatılmışlar ya da kendiliğinden gerekli üye koşullarını sağlayamadıklarından kapanmışlardır (Akyol, 2011, s. 210 - 212). 
modernist, aydınlanmacı ve devrimci siyasalarını "halka karşı, tepeden inmeci" gibi sıfatlarla eleştiriye tabi tutmuştur. Demokrat Parti, devrim (Cumhuriyet Modernleşmesi) eleştirisi ile beraber hayata geçirdiği birtakım düzenlemelerle muhafazakâr düşüncenin köklerinde olan geleneksel biçimlere ve altın dönem olarak kodlanan Osmanlı'ya göndermelerde bulunmuştur. Arapça ezan yasağının kaldırılması, 1945 yılında Türkçeleştirilen anayasa dilinin eski metne dönüşünün sağlanması ve "Anayasa" tabirinin 1952'de "Teşkilatı Esasiye Kanunu" haline getirilmesi bu kapsamda verilebilecek örneklerdir (Özer, 2015, s. 67, 68). Mert (2007, s. 74)'in ifadesi ile Batıcılıkta ileri giden CHP döneminin restore edilmesi için "Cumhuriyet devriminin muhafazakâr yorumu ve bunun siyasal karşılığı olarak" ortaya çıkan Demokrat Parti "ulusal kimlik ve ulusçuluk tanımlarının yerini, dini kültürel sembol ve değerlerle" doldurmuştur. Bora'nın altını çizdiği üzere Batı modernizmine tepki olarak gelenekselciliğe referansla gelişen muhafazakârlığın (Bora, 1999, s.70) Türkiye Cumhuriyeti tarihinde siyasal bir güç olarak iktidara gelmesini sağlayan Demokrat Parti bir yandan "Cumhuriyet devrimine karşı oluşan ve özellikle dinsel terimlerle ifade bulan tepkileri temsil ve ifade etme iddiasıyla gündeme getirip siyasallaştırmış" (Safi, 2005, s. 168) diğer taraftan da 1940'lardan itibaren ekonomik alanda benimsenen liberal çizgiyi sürdürmüştür.

Bu doğrultuda Demokrat Parti serbest ticareti geliştirmek ve Türkiye'yi uluslararası sistemin üyesi yapmak üzere bir dizi hukuki düzenlemeyi kısa sürede hayata geçirmiştir. ${ }^{19}$ Hatta bu konuda Menderes "Biz devlet olarak yeni sanayi kurmak değil, mevcut sanayi kurumlarını hususi sermayeye, hususi teşebbüse, vatandaşa devretmek hazırlığındayız” ifadesi ile liberal ekonominin temeli olarak özel mülkiyete ve özel girişimciliğe verdiği önemi açık biçimde ortaya koymuştur (Demir, 2010, s. 456).

Demokrat Parti döneminde gerçekleştirilen dönüşümler yasal birtakım düzenlemeler ve sembolik göndermelerle sınırlı kalmamış, tıpkı Cumhuriyet'in ilk yıllarında olduğu gibi bu dönemde de mekân, iktidarın sahip olduğu ideolojiyi hâkim ve görünür kılmak için kullandığ çerçevenin bir kanadını temsil eden muhafazakârlık ele alındığında, bu dönem içerisindeki mekânsal pratikler ve siyasal söylem en temelde muhafazakârlığın tüm ontolojik köklerini içinde barındırır biçimde, İstanbul-Ankara ikiliği üzerinden üretilmiştir. Mekânın modernleştirilmesi ve geleneklerden kopuş anlamında Cumhuriyet'in ilk y1llarında üretilmiş en köklü mekânsal strateji İstanbul'un unutulup, Ankara'nın imarına öncelik ve önem verilmesi iken; Demokrat Parti tam bu noktadan hareketle, kendi iktidarı döneminde sürekli İstanbul'u ön plana çıkaracak siyasal söylemleri geliştirmiş ve uygulamıştır. Demokrat Parti İstanbul vekillerinden Ahmet Hamdi Başar 1952 yılında yaptığı bir konuşmada İstanbul'un “hükümetin merkezi Ankara olduktan sonra suyu çekilmiş değirmen gibi terk edilmiş, ihmale uğramış, yürekler acısı hale gelmişs bir şehre döndüğünü belirtmiştir (Boysan, 1990b, s. 234). Benzer şekilde İstanbul'a olan büyük ilgisi nedeniyle kendisine İstanbul Belediye Meclisi tarafından fahri belediye başkanlığı ünvanı verilen Adnan Menderes (Demir, 2010, s. 466), Ankara'yı modern Cumhuriyet'in başkenti olarak önceleyen CHP'yi bir konuşmasında şu şekilde eleştirmiştir:

19 Yabancı sermayenin Türkiye’ye girişinin önü açmak üzere 1 Ağustos 1951'de "Yabancı Sermaye Yatırımlarını Teşvik Kanunu”, 18 Ocak 1954'de "Yabancı Sermayeyi Teşvik Kanunu” ve 18 Mart 1954 tarihinde "Petrol Kanunu" çıkarılmıştır. (Özer, 2015, s. 74; Eroğul, 1990, s. 82, 83). 
"Halk Partisi imardan da anlamaz. Onların uzun yıllar boyunca şu canım İstanbul'da imar namına eserimiz diye gösterebilecek neleri var? Onun için imarın ne olduğunu onlar anlayamazlar. Şu eşsiz İstanbul, onların zamanında değil midir ki böyle eskimiş, harap bir hale gelmiştir. Bizim İstanbul'da yaptıklarımız bir israf değil, bir gösteriş değil, tarihi abideleri ile tabi güzellikleri ile İstanbul Türkiye'nin en kiymetli bir mücevheridir" (Zafer, 22 Ekim 1957; Havadis, 22 Ekim 1957'den akt. Demir, 2010, s. 465, 466).

Yine gazetelere yansıyan bir başka konuşmasında Menderes, İstanbul'a verdiği değeri “Türkün en ileri sanat ve medeniyet eserlerinin tekasüf ettiği, toplandığ̀ her köşesinde ve bucağında bin bir tarihi hadisenin yaşadığı imparatorluklara merkezlik etmiş tarihi büyük şehir...İstanbul bütün Türklerin kalbinde yaşayan bir hasrettir. İstanbul milletimizin üzerinde titrediği, öğündüğü ve kendi mal, varlık ve hürriyetini en ziyade nefsine toplamış olarak sevdiği bir şehirdir" (Demir, 2010, s. 462) biçiminde ifade etmiştir. Aynı doğrultuda, ancak muhafazakâr ideolojiye daha net bir referans vermesi açısından 1957 yılındaki seçimde Menderes'in seçim sloganlarından biri “İstanbul'u ikinci bir Mekke, Eyüp Sultan Camii'ni ikinci bir Kâbe yapacağız” olmuştur (Toker, 1966, s. 158).

Görüldüğü üzere Menderes modern Cumhuriyet'in başkenti karşısında İstanbul'u Türk'ün en ileri sanat ve medeniyet eserlerinin yer aldığı ve hasretle özlenen payitaht şehri olarak görmüş, bir yandan da Mekke ve Kâbe ile özdeşleştirerek ideolojik anlamda mekân üzerinden muhafazakâr ideolojiyi besleyecek göndermelerde bulunmuştur. Bu durum bir yandan muhafazakâr ideolojinin altın dönem olarak gördüğü ve Türkiye'nin muhafazakâr kesiminde Osmanlı İmparatorluğu'na özlem şeklinde tezahür eden ideolojik konumlanışın ifadesiyken, diğer yandan da Mekke ve Kâbe gibi İslami sembolleri kullanarak mekân üzerinden kurgulanan siyasetin sembolik göstergesi olmuştur.

Demokrat Parti, İstanbul'u Ankara karşısında öne çıkarırken; muhafazakâr kitleleri bir araya getirmek ve aynı duygu yoğunluğuna sevk ederek temsil ettiği ideolojiyi diri tutmak amacıyla mekânsal temsilleri de yoğunlukla kullanmıştır. Bu kapsamda Demokrat Parti döneminde muhafazakâr ideolojiyi mekân üzerinde hâkim ve sürekli kılan en önemli unsurlarından biri camiler olmuştur. 


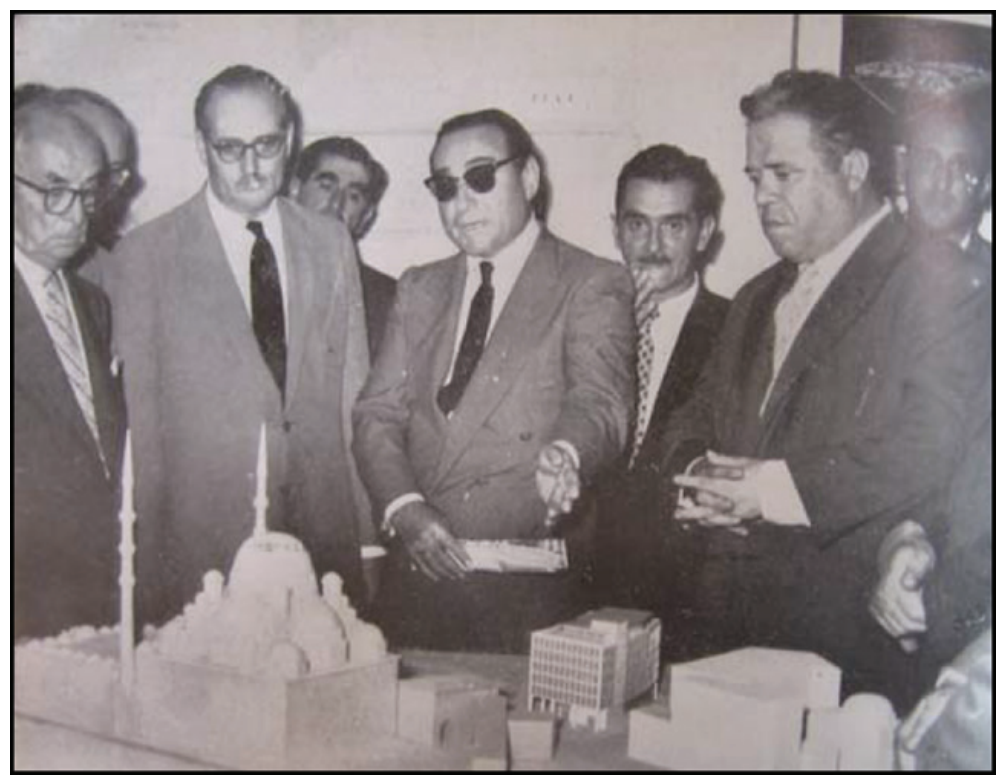

Fotoğraf 4. İstanbul'da Yürütülen İmar Faaliyetlerine İlişkin Basına Yansımış Bir Fotoğraf (Kaynak: İstanbul Kitabı, 1957, s. 13.)

Bu yeni dönemde gelenekçi muhafazakârlığın mekânsal temsili ve siyasal simge olarak cami, doğrudan en üst seviyedeki siyasal aktörler tarafından kullanılmaya başlanmıştır. “Menderes 19 Ekim 1957'de Kayseri'de seçim konuşmasında kendi dönemlerinde 15 bin caminin yaptırıldığını, başta Süleymaniye olmak üzere 86 caminin onarılıp, yeniden ibadete açıldığını söylemiştir ve kendisi Ankara'da Kocatepe Cami'nin yapılması kampanyasına 100.000 lira bağışta bulunmuştur" (Kocabaş, 2011, s. 298; Zafer 5 Kasım 1950). Demokrat Parti döneminde cami restorasyonları ve yapımı hız kazanırken (Zürcher, 2011, s. 340) popülist bir tercihle, parti yöneticilerinin camiye gitmesi yaygınlaşmış ve cami inşa eden köylere 1000-5000 TL para yardımı yapılmıştır (Kahraman, 2010, s. 281). Bu davranış iktidarın kendi gücünü dini semboller aracılığıyla görünür kılmak ve otoritesinin tartışmasızlığını kanıtlamak için Osmanlı'dan beri üretilen stratejinin 1950’lere yansıyan görüntüsü olmuştur. Bu strateji kapsamında muhafazakârlığa ilişkin mekânsal temsiller CHP ile yürütülen ideolojik mücadelede yer tutan alanlardan olmuş ve 'Demokrat Parti...CHP'lileri komünist ve dinsiz diye tanımlayarak ve Demokratların zamanında açılmış cami ve imam hatip okullarının sayısından övünçle söz ederek, dini inanç ve duygulara seslenmiştir’’20 (Zürcher, 2011, s. 338, 340).

Menderes dönemi içerisinde yürütülen imar operasyonlarının önemli bir alt başlığını oluşturan meydan düzenlemelerinin birçoğu da camileri ön plana çıkaracak biçimde

20 Demokrat Parti'den başlayan ve bugün de siyaseten zaman zaman kullanılan bir diğer söylem CHP döneminde birçok caminin depoya ve ahıra çevrildiği yönündeki söylemdir. Ancak CHP'nin tek parti olduğu dönemde böylesi bir devlet politikası neticesinde yaygın şekilde ahıra veya depoya çevrilmiş camilere rastlamak çok mümkün değildir. Ancak bu Demokrat Parti döneminden başlayarak muhafazakâr kesim tarafından sürekli diri tutulan ve kullanılan bir söylem olmuştur. Oysa Cumhuriyet'in devrimci tutumunun keskin şekilde hissedildiği ilk dönemlerinde mekânsal olarak yeni düzenlemelerin ortaya konulduğu Ankara'da, camileri ön plana çıkarmak üzere tasarım çalışmalarının yapıldığı görülmektedir ( Bkz. Cengizkan, 2004, s. 69). 
gerçekleştirilmiştir. “Cami ve Külliye'ye bir harim kazandırmak ve bu ulvi muhiti asudeliğe kavuşturmak” (Çılgın, 2010, s. 234) Beyazıt Meydanı'nın yeniden tanziminde asıl amaç olarak ortaya konulurken (Bkz. Fotoğraf 5); Tophane'nin yeniden düzenlenmesinde ise temel hedef özellikle Tophane Çeşmesi, Nusretiye ve Kılıç Ali Paşa Cami’lerinin ön plana çıkarılması (Bkz. Fotoğraf 6) olmuştur (Çılgıı, 2010, s. 236).

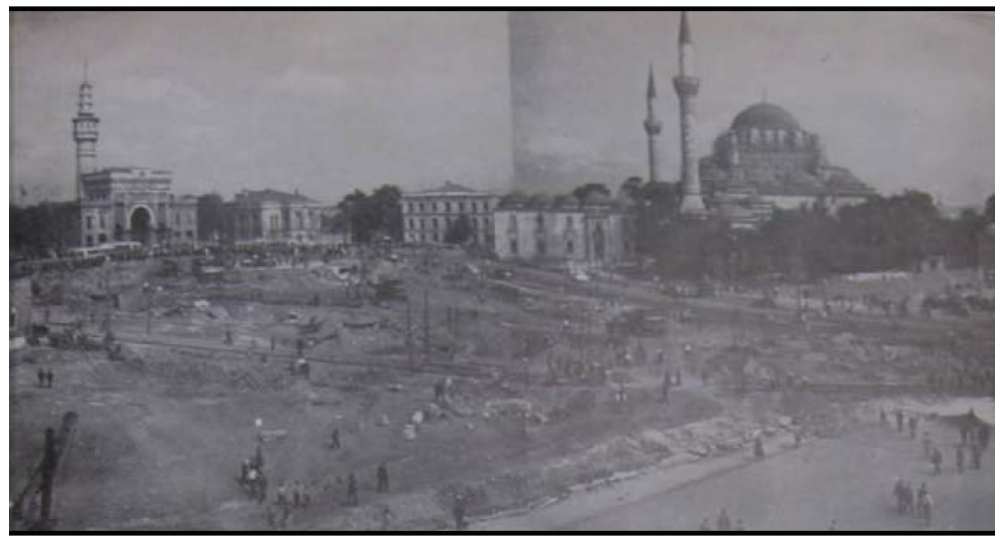

Fotoğraf 5. Beyazıt Meydan Düzenlemesi

(Kaynak: İstanbul Kitab1, 1957, s. 37, 87)

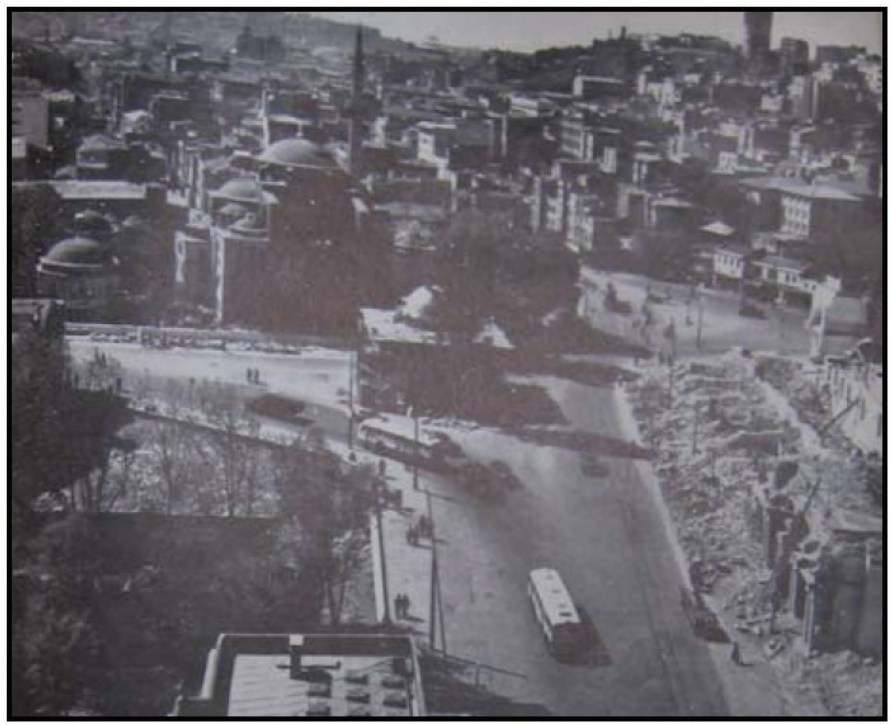

Fotoğraf 6. Tophane Meydan Düzenlemesi

(Kaynak: İstanbul Kitab1, 1957, s. 37, 87)

Bu dönem ideolojik bir simge olarak kullanılan başlıca mekânlardan biri de Ayasofya olmuştur. 1934 yılında Bakanlar Kurulu Kararnamesi ile camiden müzeye dönüştürülen 
Ayasofya, muhafazakâr cenahın muhalif tavır aldığı konularda her daim atıfta bulunulan ortak bir mekânsal kod olmuştur (Özekmekçi, 2012, s. 283). 1928 y1lında hutbelerin, 1932 yılında da ezanın Türkçe olarak ilk kez okutulduğu yer olarak Ayasofya'nın 1934 yılında müzeye çevrilmesi Akçay (1968, s. 36,37) ve Boyar (1943)'a göre yeni rejimin bu mekân üzerinden kendi iktidar gücünü seküler bir biçimde tescilleme gayretinin ifadesi olarak görülmüştür. Ancak muhafazakâr kesimin yüzyıllar boyunca batı karşısında bir üstünlük nişanesi olarak kodladığı ve Osmanlı'nın altın dönemiyle özdeşleştirdiği “Ayasofya'nın etrafina örülen anlam halkasının temelleri, bu kesimin Demokrat Parti iktidarıyla kendi sesini görece daha rahat duyurabilme imkânına kavuştuğu 1950'lerde özellikle de İstanbul'un fethinin 500. yılının kutlamaları çerçevesinde" gün yüzüne çıkmıştır (Özekmekçi, 2012, s. 283). Bu doğrultuda mekânsal ideolojik bir simge olarak Ayasofya ilk kez bu dönemde yoğun biçimde kullanılmaya başlanmış ve 1952 yılı Ankara İl Kongresi'nde Ayasofya'nın cami haline getirilmesi önerilmiştir (Eroğul, 1990, s. 80). Bu durum muhafazakârlığın mekânsal anlamda ortaya koyduğu Dar'ül İslam (mekânın İslamlaştırılması) stratejisinin tipik bir örneği olmasının yanında, "altın dönem" olarak kodlanan Osmanlı dönemine öykünme ve göndermenin güçlü bir ifadesi olmuştur.

Elbette muhafazakâr yaşam biçimini mekânda ve gündelik hayatta hâkim kılmak için kullanılan tek yapısal dini form cami ve Ayasofya olmamıştır. Demokrat Parti döneminde devlet eliyle yapılan düzenlemelerin yanında, sivil alanın da önü açılmış ve hatta Mert (2007, s.15) tarafından bu dönem Türk halkının vatandaşlık ve demokrasi bilincinin geliştiği yıllar olarak tanımlanmıştır. Bu doğrultuda 1950-1960 arası bu süreçte dernekleşme sayısı artmış, bu artıştan en büyük payı da İslamcı karakteri ağır basanlar başta olmak üzere muhafazakâr karakterli dernekler almıştır. ${ }^{21} \mathrm{Bu}$ dernekler bir yandan dinci-İslamcı kitlelerin siyaset arenasına çıkışını kolaylaştırmış (Şen, 1995, s. 16), diğger taraftan da ideolojik yayılma noktaları olarak, mekânda eriştikleri yoğunlukla mekânın ve gündelik hayatın muhafazakârlaştırılmasında önemli yapılar olarak yer tutmuşlardır.

Burada belirtmek gerekir ki, iktidar tarafından sivil alanın önünün açılmasının yanında kırdan kente yoğun göç ${ }^{22}$ neticesinde toplumsal yapıda meydana gelen dönüşüm, muhafazakârlığa ilişkin söylem ve eylem sahibi derneklerin sayısının artışını ve toplumun muhafazakârlaşmasını etkileyen temel unsurlardan olmuştur. $\mathrm{Bu}$ anlamda kentlerde muhafazakârlığın yükselişi; kırsal kesimden kentlere göç eden, tarımsal üretim ve feodal yaşam biçiminden, sanayi ve ona bağlı toplum kurgusu içerisine dâhil olan bireyin sosyal ve psikolojik durumuyla yakından ilişkili olmuştur. Sanayileşen kent alanına kırdan gelen birey kırsal kesimdeki bütünlük (sosyal hayat-mekân-iş yaşamı) duygusunu aramıştır. Aşırı özelleştirilmiş ve ihtisaslaşmış kurgusu ile kentsel yaşam; kırdan göçmüş bireyde yalnızlık duygusu yaratmış ve "köyden kente yeni göç etmiş kişiler, kent ortamında kendilerini güvenlik içinde hisse[dememişlerdir]" (Kartal, 1983, s. 230). Bu noktada din yalnızlaşan bireyin yalnızlık duygusunu gidereceği, kırsal kesimde var olan belirli ritüel

211946 yılında 11 olan toplam cami yaptırma ve dini dernek sayısı 1960 yılında 5104'e ulaşmıştır. Bu sayı hem toplamda hem de artış oranı itibariyle cami ve dini derneklerin diğer tüm dernek türlerini geride bıraktığını göstermektedir. (Yücekök, 1971, s. 133).

22 1950'den başlayarak kentli nüfusa her sene 1,5 milyon kır kökenli nüfus eklenirken, bu nüfus akımının kent mekânına yansıması olarak ortaya çıkan gecekondu sayısı bu koşullarla örtüşür şekilde artmıştır. 1955'de kentsel nüfusa oranı \%4.69 olan gecekondu miktarı, 1960'a gelindiğinde \%16'ya ulaşmıştır (Keleş ve Payne'den akt. Şengül, 2009, s. 124). 
ve sembolleri kentte yaşayabileceği bir işleyişi yalnız bireye sunmuştur. ${ }^{23}$ Dini dernekler tam bu noktada kırdan kente göç eden kitlelerin içerisinde bulundukları psikolojik duruma ve bununla ilişkili olarak kültürel ihtiyaçlara organize şekilde cevap veren birimler olarak sayılarını hızla artırmışlardır.

Kırdan göç eden muhafazakâr karakteri ağır basan kitlelerin yaşam alanı olarak ortaya çıkan gecekondu ise "içinde yaşadığı bireyi, yabancı ve düşman kent yaşamından korumakla, ona yaşama firsatı sağlamakla” (Kongar, 1982, s. 31), kırsal karakterli yaşam biçiminin, kültürel ve dini ritüellerin kentsel alanda sürdürülmesine olanak sağlayan bir yerleşim formu olarak işlev görmüştür. Gecekonduların gördükleri bu işlevi Karpat “...gecekondu yerleşimi aşina olunan kültürel ilişkilere süreklilik sağlayan göçmenin yabancılaşma tehlikesini asgariye indirmekte ve görece derli-toplu bir tarzda tedrici olarak kentsel yaşantıya geçişini hazırlamaktadır" biçiminde dile getirmiştir ${ }^{24}$ (Karpat, 2003, s. 85). Bu geçiş sürecinde gecekondulardaki yeni kentli nüfus, kırsal kesimden kalma alışkanlıklarını koruma refleksinde olduğundan aynı zamanda muhafazakâr ideolojinin kırsal alandan kent mekânına aktarılmasında önemli görev üstlenmişlerdir. $\mathrm{Bu}$ durum Mardin tarafından şu şekilde ifade edilmiştir:

"Bu bölgelere göç edenler, ..., dinin merkezi bir yer işgal ettiği, kendi özgün yerleşimlerini yeniden oluşturdular. Bu bölgelerde, çoğunlukla yerel destekle camiler inşa edildi. Burada günlük yaşamın Müslüman ritmi, şehir merkezindekinden çok daha belirgindir. İnsan, ilk nesil söz konusu olunca, gecekondudaki yaşamın "1lımlı” İslam'ın şehre başarılı bir transferi olduğunu hissediyor" (Mardin, 1991, s. 223).

Kendini liberal demokrat bir parti olarak tanımlayan Demokrat Parti döneminde, kentsel mekâna yönelik yapılan düzenlemeler ve değişim sadece muhafazakârlıkla sınırlı kalmamıştır. Cumhuriyet'e karşı eleştirilerini gelenekselci ve kültürel formlara dayalı olarak ortaya koyan; ancak bir taraftan da ekonomik gelişme hedefini kabul eden ve bu alanda liberal ekonominin gereklerini sahiplenen Demokrat Parti döneminde kentsel mekân muhafazakârlığın hâkim kılınmasına yönelik düzenlemelerle birlikte, liberal ekonominin gerekleri doğrultusunda da köklü şekilde değişime uğramıştır.

Bu dönem kentsel mekânda hayata geçirilen uygulamalar, doğrudan Başbakan Adnan Menderes'le ilişkilendirilerek “Menderes Operasyonları” olarak adlandırılmış ve ağırlıkla İstanbul'da yoğunlaşmıştır. Dönem içerisinde kentsel alanda sürdürülen inşaat faaliyetleri sanayi yatırımlarının önünde görülerek ekonomik anlamda ağırlık inşaat sektörüne verilmiştir. $\mathrm{Bu}$ durum 1957 Yerel Seçim konuşmalarından birinde Adnan Menderes tarafından şu şekilde dile getirilmiştir: "İstanbul'a imar ve ümran bakımından yapılacak hizmetler, memlekete bin fabrika kurmaktan daha verimlidir....Bugün İstanbul'un

23 Kartal yaptığı çalışmalar içerisinde gecekondularda yaşayan kitlelerin kentte kalış süreleri arttıkça eskiden ihmal ettikleri dini görevleri (namaz, cuma namazı, oruç, kurban kesme) daha çok yerine getirdiklerini ortaya koymuştur (Kartal, 1983, s. 235, 243; Kartal, 1978, s. 108, 109).

24 Gecekondular aynı zamanda Demokrat Parti tarafından iktidar gücünü artıracak alanlar olarak görülmüştür. Demokrat Parti gecekondulu nüfusun politik önemini keşfetmiş ve gecekondu nüfusu da kendi açısından bu süreçte oy potansiyelini, mekânda hâkimiyet kurmada pazarlık aracı olarak kullanmaya başlamıştır. Gecekondu bölgelerinde parti ocaklarına kayıt karşılığı tapu dağıtıldığı, altyapı getirildiği dönem gazetelerine yansımış (Şenyapılı, 1981, s. 45, 46) ve yapılan birçok çalışmada gecekondu bölgelerinde yaşayan kişilerin bizatihi kendileri tarafından bu durum doğrulanmıştır (Şentürk, 2015, s. 24). Bu simbiyotik ilişki içerisinde gecekonduda yaşayan "bu kesimler kırdan getirdikleri değerleri özellikle kente varışlarının ilk yıllarında tutucu bir biçimde yeniden üretirken, siyasal eğilimleri de daha çok muhafazakâr partileri desteklemek yönünde olmuştur" (Şengül, 2009, s. 127). 
imarında çalıştırdığımız yol makinelerinin miktarı, 1950'de bütün Türkiye'de faaliyette bulunan yol makinelerinin iki mislinden fazladır" (Bayar, tarih belirtilmemiş, s. 161). Benzer biçimde ekonomik gelişme ile kentsel mekânın üretimi arasında kurulan bu ilişkiyi 23 Eylül 1956 tarihinde düzenlediği bir basın açıklamasında Menderes "İktisadi potansiyel bakımından Türkiye'ye bir Türkiye daha ilave ediliyor" (Çılgın, 2010, s.171) biçiminde ifade etmiştir.

Diğer taraftan da Menderes politik pozisyonu ile ilişkili siyasal gücünü ve ideolojik duruşunu adeta kentsel mekândaki bu yıkıcı uygulamalar ile görünür kılmıştır. Boysan'ın (1990b, s.235) ifadesi ile "küçük bir sokağın açılmasının yıllarca sürdüğü İstanbul'da alışılmamış genişlikte bulvarlar açılması Demokrat Parti'nin gelişme niyetinin hiçbir sınır tanımadığını göstermiş̧tir]." Bu bakış açısı neticesinde ağırlığı İstanbul'da olmak üzere kentler yoğun bir yıkım sürecine girmiştir. Özellikle araç trafiğini önceleyen politikalar neticesinde kentler geniş bulvarlarla, meydan düzenlemeleri ve kent projeleri ile tanışmış, İstanbul neredeyse bir şantiyeye dönüşmüştür (Bkz. Fotoğraf 7, 8 ve Şekil 1).

$\mathrm{Bu}$ durum esas itibari ile Demokrat Parti'nin iktisadi kalkınmaya verdiği önceliği göstermektedir. Bu bakış o kadar keskin olmuştur ki, iktisadi kalkınmada inşaat sektörüne öncelikli yer veren Demokrat Parti, bu doğrultuda muhafazakâr bir parti olarak İstanbul'un birçok tarihi bölgesinin bozulmasına sebep olacak imar faaliyetlerine girişmekten çekinmemiştir. $\mathrm{Bu}$ operasyonların bedeli o kadar büyük olmuştur ki Tekeli’nin vermiş olduğu rakamlara göre, yaklaşık olarak 3,5 yıl süren operasyonlarda İstanbul Belediyesi'nin istimlak ettiği bina sayısı 7289, istimlak için tahakkuk eden değer 536.000.000 TL. olmuştur. İstimlak dışında ise İstanbul Belediyesi imar faaliyetleri için 117.000.000 TL. harcamıştır. 1956 yılında tüm Türkiye belediyelerinin gelirleri toplamının 434.000.000 TL. olduğu düşünülürse İstanbul'da girişilen operasyonların maddi büyüklüğü çarpıcı şekilde ortaya çıkmaktadır'25 (Tekeli, 2009, s.171).

25 Benzer şekilde bir kıyaslama Demokrat Parti ve CHP dönemleri arasında yapıldığında Demokrat Parti'nin yedi yılda yıkım ve yol yapımı için yaptığı harcamanın, CHP'nin 27 yıllık iktidarında harcanan miktardan 4.5 kat fazla olduğu görülmektedir. Yine Demokrat Parti döneminde istimlak için harcanan paranın miktarı da bütün bir erken Cumhuriyet döneminde bu amaçla harcanan paranın 13 katına eşittir (Gül, 2009, s.150). 


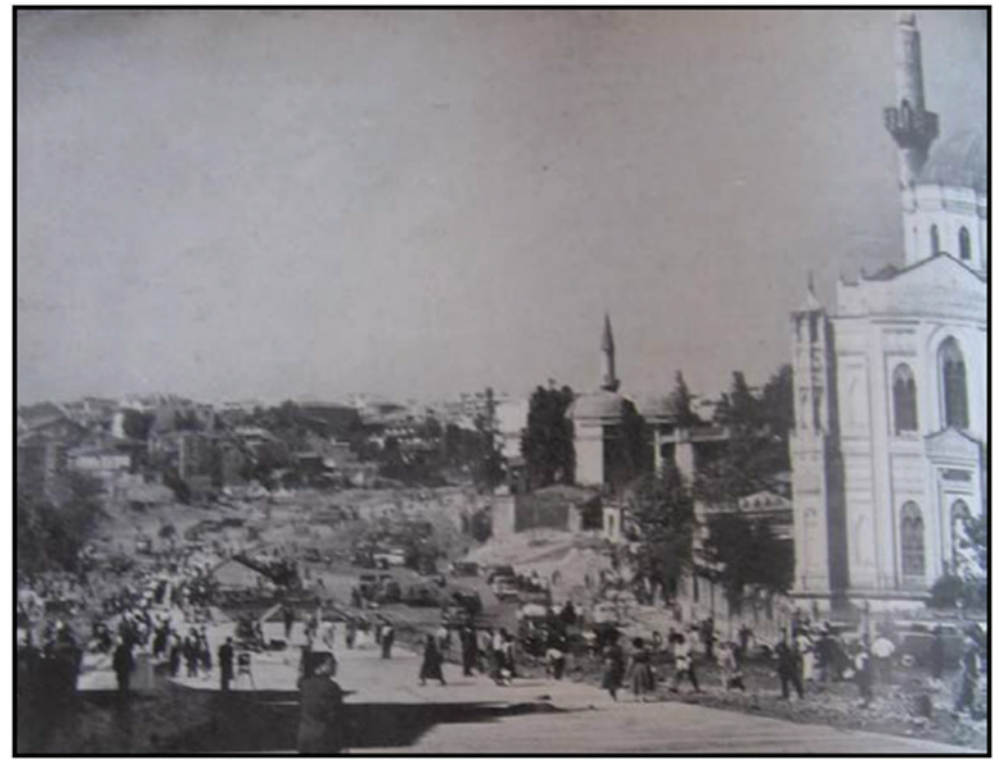

Fotoğraf 7. Millet Caddesi Üzerinde Süren İnşaat Faaliyetlerinden Görünüm (Kaynak: İstanbul'un Kitabı, 1957, s. 36.)

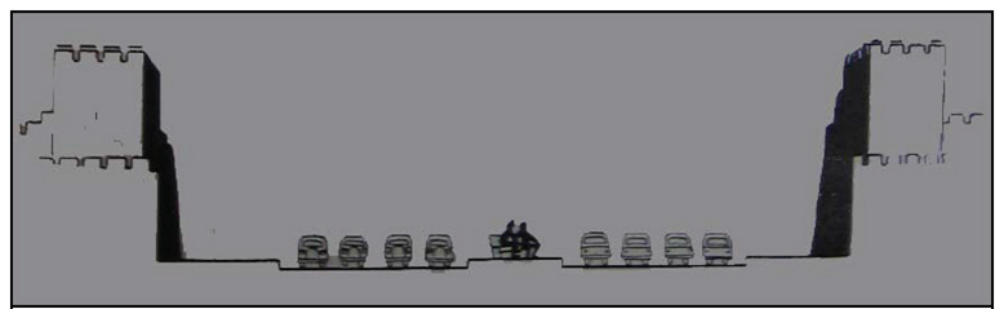

Şekil 1. Millet caddesi'nin kesiti

(Kaynak: İstanbul'un Kitabı, 1957, s. 17.) 


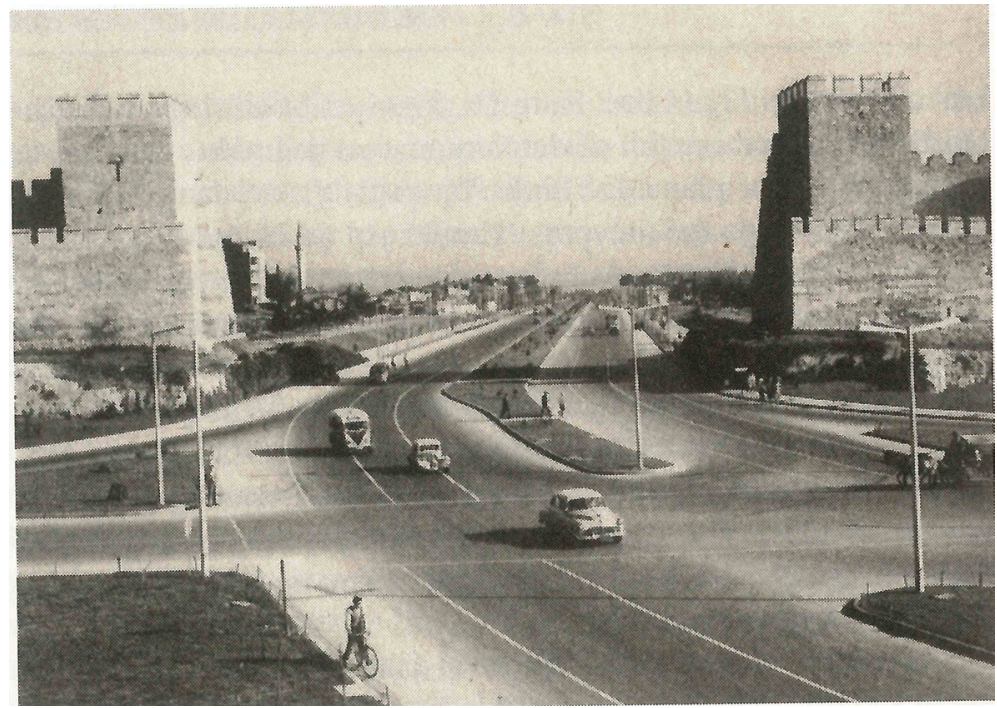

Fotoğraf 8. Millet Cami İnşaatı Sonrası Surların Görünümü

(Kaynak: Gül, M., (2009) The Emergence of Modern İstanbul, Touis Academic Studies, London)

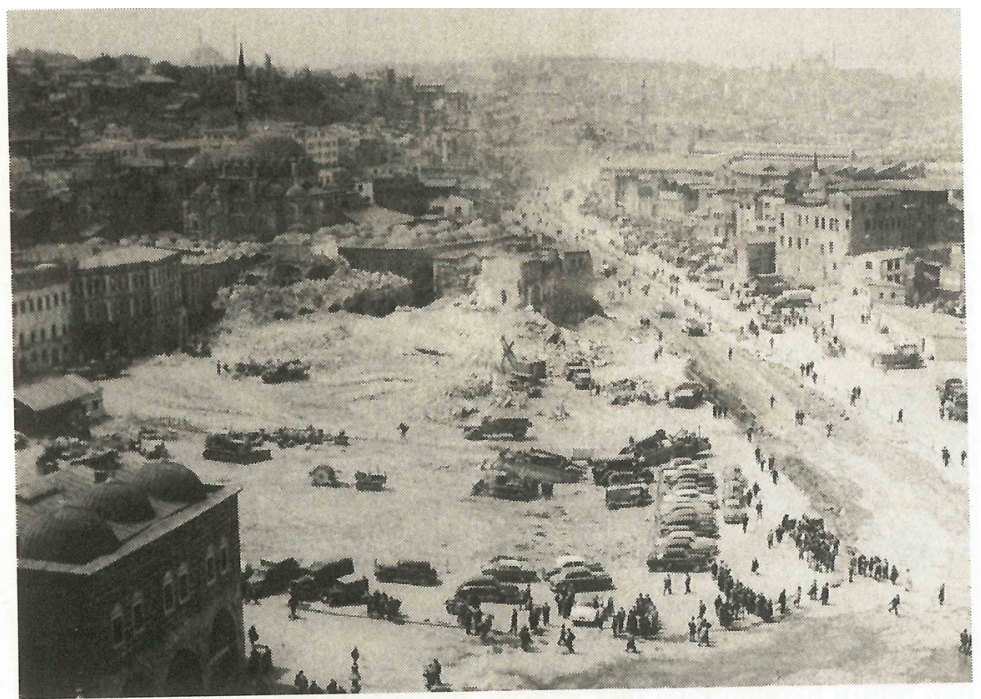

Fotoğraf 9. Eminönü Meydanı Düzenlemeleri Kapsamında Yürütülen Yıkım ve İnşa Faaliyetleri

(Kaynak: Gül, M., (2009) The Emergence of Modern İstanbul, Touis Academic Studies, London) 
Menderes'in İstanbul'da gerçekleştirdiği bu yoğun dönüşüm esas itibariyle modernizmi muhafazakâr bir çerçevede ele alan siyasal tutumun kent mekânına yansımasıdır. İktisadi kalkınmaya önem veren Demokrat Parti şehirleri modern bir çehreye kavuşturmaya çalışırken; kentlerde giriştiği yoğun yıkım yapım süreçlerini bir yandan da muhafazakâr kimliğe ilişkin göndermeler eşliğinde hayata geçirmiştir. Hatta İstanbul'da yaşanan yoğun yıkım-yapım sürecini Menderes, “İstanbul'un imarı mevzuu adeta bir zafer alayının hikâyesidir. İstanbul'u bir kere daha fethedeceğiz” ( Gül, 2009, s. 140) cümlesinde olduğu gibi İslamcı bir dil içerisinde, fetih inancı ile özdeşleştirerek gerçekleştirmiştir. Benzer şekilde yürüttüğü imar operasyonlarında ayrıştırıcı bir tutum sergileyen Menderes, bunu net şekilde "bir metre gavur kaldırımı yapmadım!” (Boysan 1990a, s. 231) ya da "İstanbul'u yedi tepeye kuran Bizans değil biziz. Türklerdir... İlk yapılması gereken şey: Beyoğlu'na karşı İstanbul!” (Bayar, tarih belirtilmemiş, s. 159) cümlelerinde olduğu gibi gayrimüslim kimlik karşıtlığını, bu kişilerin yoğunlukla yaşadıkları Beyoğlu üzerinden üreterek göstermiş, hatta bu kişileri “Osmanlı mirası İstanbul"un karşıtı gibi göstermeye çalışmıştır. Kentsel mekân üzerinden ortaya konulan bu ayrıştırıcı tutum Boysan tarafından "Vatan Cephesi kurarak halkı bölmeye girişenler şehrin semtlerini de birbiri karşısına getirmeye çalışmaktan çekinmiyorlardı" (Boysan, 1990a, s.231) biçiminde ifade edilmiştir.

Görüleceği üzere kendini liberal-muhafazakâr bir parti olarak tanımlayan Demokrat Parti'nin mekâna ilişkin politikaları bu iki ideolojinin de izlerini barındırmıştır. Muhafazakârlığailişkin göndermelerbelirli söylemlervesembollerüzerinden gerçekleşirken, inşaat sektörünü ekonominin itici gücü olarak benimseyen Demokrat Parti’nin politikaları kentlerde yoğun bir yıkım-yapım süreci yaratmıştır. Bu yıkıcı tavır öylesine uç seviyelerde gerçekleşmiştir ki, İstanbul'un Osmanlı mirasını da içerisinde barındıran birçok tarihi alan bu uygulamalar neticesinde yok olmuştur. Ayrıca ekonomi politikalarında inşaata öncelik veren tavır neticesinde kentsel mekan büyük paraların kazanıldığı bir alan haline gelmiş ve kentsel mekanın sadece devlet eliyle değil özel sermaye (müteahhit) tarafından dönüştürüldüğü kontrolsüz bir süreç başlamıştır. Bu dönüşüm süreci içerisinde planlama artık mekânı kamusal güdüler doğrultusunda düzenlemeye yarayan bir araçtan çok sermaye artırımına yarayan bir araç biçimine dönüşmüştür.

Bu dönem artık Cumhuriyet'in kuruluş yıllarında olduğu gibi mekânın, I. ve II. Ulusal Mimarlık Akımları gibi entelektüel ve estetik zenginliği artırıcı tartışmalar eşliğinde şekillendiği; heykeller ve modern mimarlığı temsil eden yapıların kendini baskın biçimde kentsel mekânda görünür hale getirdiği bir dönem değildir. Bu dönem içerisinde mekânda ikili bir yapı hâkim hale gelmiş ve muhafazakâr yaşama ilişkin semboller ve kurumların kentsel mekânda temsilleri artmaya başlarken, kentler keskin biçimde bir yıkım-yapım sürecine girmişlerdir. Kent toprağının zenginleşme aracı olarak keşfedildiği bu dönemde kentlerde yaşanan yıkım süreci çoğu zaman muhafazakârlığa ilişkin göndermelerle hayata geçirilmiştir. Bu anlamda Cumhuriyet'in ortaya koyduğu modernizm vizyonunu kökten reddetmeyen ve iktisadi kalkınmaya öncelik veren, ancak Erken Cumhuriyet Dönemi'ne kültürel bir çerçeve içerisinde gelenek ve din üzerinden eleştirilerini yönelten Demokrat Parti dönemi, liberalizmle muhafazakârlığın koalisyon kurduğu ve birbirlerini besledikleri bir dönem olurken; kentler, bu süreçte ortaya çıkan koalisyonun hem sahnesi hem de harcı olarak görev yapmışlardır. 


\section{Sonuç}

Türkiye Cumhuriyeti Osmanlı'nın son döneminden itibaren uç veren modernleşmeci çizginin nihai aşaması olarak tarih sahnesine çıkmıştır. İslam coğrafyasının en radikal dönüşümlerinin birini gerçekleştiren Türkiye Cumhuriyeti; idari ve hukuki alanlarla birlikte gündelik yaşamı da tümden değiştirecek devrimci atılımları ardı ardına gerçekleştirirken; muhafazakâr kutup ile sürdürdüğü mücadelede mekân, en önemli belirleyenlerden biri olarak yer almıştır.

Bu anlamda 1923-1945 arası dönemde Cumhuriyet modernleşme ideali doğrultusunda inkılapları hayata geçirirken, bu inkılapların pratikte deneyimleneceği ve gündelik hayatın dönüştürüleceği yer olarak kentsel mekânı devrimci biçimde dönüşüme sokmuştur. Cumhuriyetin ilk yıllarında kurucu kadronun aydınlanma politikaları neticesinde, muhafazakâr yaşam tarzı ve bu yaşam biçimine ilişkin mekânsal sembol ve kurguların hâkimiyeti belirli büyükşehirlerde kaybolmuş; yerini batı tarzı modern yaşama ait, mekânsal kurgu, semboller ve gündelik yaşam pratikleri almıştır. Yeni rejim mekânideoloji diyalektiği çerçevesinde başta, kendine başkent olarak seçtiği Ankara olmak üzere belirli şehirlerde bu pratikleri batılı mimarlar ve plancılar eliyle gerçekleştirirken; bireyi önceleyen, özgürlükçü kamusal kullanımların yer aldığı bir mekân kurgusunu hayata geçirmiştir. Ancak bu aydınlanmacı dönüşüm hedefi, ekonomik yetersizlikler, devrim sürecinin yarattığı ani kültürel kırılma ve bu kırılmanın etkisinin coğrafya üzerinde eşitsiz şekilde gerçekleşmesi sebebiyle sadece kısıtlı bir coğrafyada gerçekten başarılı olabilmiştir. Mekânsal anlamda toptan bir dönüşüm başarılamadığı için de cumhuriyet aydınlanması ile muhafazakâr düşünce dünyası arasındaki ideolojik gerilim; mekân boyutuyla da görünür ve hissedilir hale gelmiştir.

1923-45 döneminden farklı olarak 1945-60 arası dönemde devlet yönetiminde meydana gelen ideolojik kırılma kentsel mekânın bambaşka bir şekilde biçimlenmesiyle sonuçlanmıştır. Bu dönem bir yandan liberal ekonomi modelini benimseyen DP iktidarının kent toprağını rant üretme anlamında keşfettiği, bu doğrultuda yıkıcı politikalarla kentleri yıkım-yapım sürecine soktuğu; aynı zamanda da ideolojik konumlanışının ikinci kanadını oluşturan gelenekçi muhafazakarlığa ilişkin sembol ve düzenlemeleri mekanda gerçekleştirdiği bir dönem olmuştur.

İki uçlu gibi görülen bu dönüşüm çoğu zaman iç içe geçmiş biçimde, adeta bir koalisyon içerisinde gerçekleşmiş; en yıkıcı müdahaleler muhafazakârlığa ilişkin göndermelerle hayata geçirilirken, kent arazisi üzerinden büyük ölçekli kar elde etmek mümkün hale gelmiştir. Sivil alanda meydan gelen serbestleşmeden de en çok muhafazakâr karakterli dernek ve sivil toplum kuruluşları yararlanmış ve sayıları bu dönem içerisinde hızlı biçimde artmıştır. Bu dönemde gerçekleşen kırdan kente göç neticesinde kıra ait kültür ve davranış kodları kentsel mekânda görünür hale gelmiş; kentler muhafazakârlığa ilişkin kodları barındıran (bölünmüşlük, içe kapalılık, mahremiyet) gecekondu bölgeleriyle tanışmışlardır. Kırdan kente göç eden bu kitleler aynı zamanda muhafazakâr dernek ve kuruluşların da büyüyebilecekleri uygun habitatları yaratmışlardır. Demokrat Parti döneminde gerçekleşen tüm söylem ve pratikler oldukça etkili olmuş ve birçok yabancı yazar, Demokrat Parti ile birlikte İslamcı bir dirilişin yeniden başladığını ileri sürmüştür (Lewis, 1952, s. 38-48; Reed, 1954, s. 267-282). 
Netice itibariyle Cumhuriyet'in kuruluş aşamasında önemli ideolojik kırılmaları içeren 1923-1945 ve 1945-1960 arası dönemler içerisinde mekân, hem bu ideolojilerin hayat bulduğu sahne, hem de iktidarların ideolojilerini gündelik hayatta hâkim kılmak için kullandıkları stratejik bir araç olmuştur.

Hakem Değerlendirmesi: Dış bağımsız.

Çıkar Çatışması: Yazar çıkar çatışması bildirmemiştir.

Finansal Destek: Yazar bu çalışma için finansal destek almadığını beyan etmiştir.

Peer-review: Externally peer-reviewed.

Conflict of Interest: The author has no conflict of interest to declare.

Grand Support: The author declared that this study has received no financial support.

\section{Kaynakça/References}

Ahmad, F. (1991). Politics and Islam in modern Turkey. Middle Eastern Studies, 27, 3-21.

Akçay, İ. (1968). Ayasofya Camii. Hakses Neşriyat, Ankara.

Akıncı, M. (2012). Türk Muhafazakârlı̆̆ı, Çok Partili Siyasal Hayattan 12 Eylül'e. İstanbul: Ötüken Yayınevi. Akşin, S. (2012). Kısa Türkiye Tarihi. İstanbul: Türkiye İş Bankası Yayınları.

Akyol, H. (2011). Türkiye’de Sağ Örgütler. Ankara: Phoenix Yayınevi.

Bayar, C. (Tarih Belirtilmemiş). Başvekilim Adnan Menderes, (Der. İsmet Bozdağ). İstanbul: Baha Matbaası.

Black, C. E. (1986). Çăgdaşlaşmanın İtici Güçleri, (Çev. Fatih Gümüş). Ankara: Türkiye İş Bankası Kültür Yayınları.

Bora, T. (1997). Muhafazakârlığın değişimi ve Türk muhafazakârlığının bazı yol izleri, Toplum ve Bilim Dergisi, 74, 6-30.

Bora, T. (1999). Türk Sağının Üç Hali. İstanbul: Birikim Yayınları.

Boyar, A. S. (1943). Ayasofya. İstanbul: İstanbul Maarif Matbaası.

Boysan, A. (1990a). "Adnan Menderes Belediyeciliği İmar Hareketi Uygulama ve Sonuçları"; Türk Belediyeciliğinde 6o Yll Uluslararası Sempozyum, Metropol İmar A.Ş. IULAEMME, Ankara, s. 225-233.

Boysan, B. (1990b). "Menderes Dönemi Belediyeciliği/İmar Hareketleri, 'Halkla İlişkiler' Stratejisi Olarak İstanbul'un İmarı", Türk Belediyeciliğinde 6 o Yll Uluslararası Sempozyum, Metropol İmar A.Ş. IULAEMME, Ankara, s. 234-240.

Cengizkan, A. (2004). Ankara’nın İlk Planı 1924-25 Lörcher Planı. Ankara: Ankara Enstitüsü Vakfı.

Çılgın K. (2010). Milli Hicabı Aşmak” Üzere: 1940-1960 Arası CHP ve DP Dönemi Kent Politikaları (Yayınlanmamış Yüksek Lisans Tezi), Mimar Sinan Güzel Sanatlar Üniversitesi Fen Bilimleri Enstitüsü, İstanbul.

Çiğdem, A. (1997). Muhafazakârlık üzerine. Toplum ve Bilim Dergisi, 32-50.

Çiğgdem, A. (2001). Taşra Epiği Türk İdeolojileri ve İslamcılık. İstanbul: Birikim Yayınları.

Demir, Ş. (2010). Türk Siyasi Tarihinde Adnan Menderes. İstanbul: Paraf Yayınları.

Dubiel, H. (1998). Yeni Muhafazakârlık Nedir? (Çev. Erol Özbek). İstanbul: İletişim Yayınları.

Eroğul, C. (1990). Demokrat Parti Tarihi ve İdeolojisi, İmge Kitabevi, Ankara.

Ertan, T. F. (1994). Kadrocular ve Kadro Hareketi, No: 29. Ankara: Kültür Bakanlı̆̆ı Yayınları.

Ertuna, C. (2004). Taştaki İz Belgeseli. İstanbul: Yön.

Ete, H. (2003). Modernleşme ve Muhafazakârlık Kıskacında Türkiye'de İslamcılığın Gelişimi. Tezkire, 33, $42-63$.

Faroqhi, S. (1997). Osmanlı Kültürü ve Gündelik Yaşamm: Ortaçağ’dan Yirminci Yüzyıla. İstanbul: Tarih Vakfi.

Georgon, F. (1996). Keçi Kılından Kalpağa: Osmanlı İmparatorluğu’nun Son Yüzyılında Ankara'nın Gelişimi, (Der. P. Dumont ve F. Georgeon), Modernleşme Sürecinde Osmanlı Kenti. İstanbul: Tarih Vakfı Yurt Yayınlar1, 99-115.

Geray, C. (2008). Şehirciliğimiz ve Ankara. Mülkiye Dergisi, 32(261), 9-26.

Gül, M. (2009). The Emergence of Modern Istanbul, Touris Academic Studies, London.

Güler E. Z. (2009). Muhafazakârlık: Kadim Geleneğin Savunusundan Faydacılığa, 19. Yüzyıldan 20. Yüzyıla Modern Siyasal İdeolojiler (Der. H. Birsen Örs). İstanbul: İstanbul Bilgi Üniversitesi Yayınları.

Günay, B. (2005). Türkiye Mimarlığı: Gelenek, Yöre, Doğu, Batı. Ankara: Şehir Plancıları Odası Yayınları.

Hanioğlu, Ş. (1981). Bir Siyasal Düşünür Olarak Doktor Abdullah Cevdet ve Dönemi. İstanbul: Üçdal Neşriyat.

İstanbul'un Kitabı (1957). Dönemin iktidar partisi DP tarafindan İstanbul Vilayeti Neşriyat ve Turizm Müdürlüğ̈̈’ne hazırlatılmış olan faaliyet raporudur.

İrem, C. N. (1997). Kemalist modernizm ve Türk gelenekçi-muhafazakârlı̆̆ın kökenleri. Toplum ve Bilim Dergisi, 74, 52-99.

Karaosmanoğlu, Y. K. (1987). Panaroma. (3. Baskı). İstanbul: İletişim Yayınları. 
Karpat, K. H. (2003). Türkiye'de Toplumsal Dönüşüm: Kırsal Göç, Gecekondu ve Kentleşme.Ankara: İmge Kitabevi.

Kartal, S. K. (1978). Kentleşme ve İnsan. Ankara: Türkiye Ortadoğu Amme İdaresi Enstitüsü, Yayın No: 175.

Kartal, S. K. (1983). Ekonomik ve Sosyal Yönleriyle Türkiye'de Kentlileşme. Ankara: Yurt Yayınları.

Keleş, R., \& Payne, G. (1984). "Turkey”, M.Wynn (der.), Planning and Urban Growth in Southern Europe, Londra: Mansell.

Kılınç, K. (2009). Öncü Halk Sağlığı Projelerinin Kamusal Mekânı Olarak Sıhhiye (Der, G. A. Sargın), Başkent Üzerine Mekân Politik Tezler Ankara’nın Kamusal Yüzleri, 2. Baskı, İletişim Yayınları, İstanbul, s.119-156.

Kırçak, Ç. (1989). Meşrutiyetten Günümüze Gericilik (1876-1956) 1. Kitap. Ankara: Bilar Yayınları.

Kimyon, D, ve Serter, G. (2015). Atatürk Orman Çiftliği’nin ve Ankara’nın değişimi ve dönüşümü. Planlama Dergisi, 25(1), 44-63.

Kocabaş, S. (2011). TC Devleti Tarihi V, Menderes Dönemi DP İktidarl ve 27 Mayls 1960 Darbesine Giden Yol (1950-1960), Süleyman Kocabaş Kütüphanesi TC Devleti Tarihi Dizisi 5, Kayseri.

Kongar, E. (1982). Kentleşen Gecekondular Ya da Gecekondulaşan Kentler Sorunu, Kentsel Bütünleşme, Türkiye Gelişme Araştırmaları Vakfi Ortak Semineri, Yayın No:4, (Yay. Haz. Tököz Erder) Türk Sosyal Bilimler Derneği, s.23-54.

Kuban, D. (1996). Istanbul and Urban History, The Economic and Social History Foundation of Turkey. İstanbul: Numune Matbaacilik,

Laroi, A. (1993) Tarihselcilik ve Gelenek, (Çev. Hasan Bacanlı). Ankara: Vadi Yayınları.

Lefebvre, H. (2014). Mekânın Üretimi, (Çev. Işı1k Ergüden). İstanbul: Sel Yayıncılık.

Lefebvre, H. (2013). Kentsel Devrim, (Çev. Selim Sezer). İstanbul: Sel Yayıncılık.

Lefebvre, H. (2015). Şehir Hakkı, (Çev. Işık Ergüden). İstanbul: Sel Yayıncılık.

Lewis, B. (1952). Islamic Revival in Turkey. International Affairs (Royal Institute of International Affairs), 28(1), 38-48.

Mannheim, K. (1927). Das konservative Denken, Schumann (1984) içinde, s. 24-75.

Mardin, Ş. (1991). Türkiye'de Din ve Siyaset, Makaleler 3, (Der. Mümtaz’er Türköne-Tuncay Önder). İstanbul: İletişim Yayınları.

Mert, N. (2007). Merkez Să̆ın Kısa Tarihi. İstanbul: Selis Kitapları.

Meşe, İ. (2006). Modernleşme Sürecinde Türk Siyasal Kimliklerinde Muhafazakâr ve Yenilikçi Tavırlar. Muhafazakâr Düşünce, 3(9-10), 125-147.

Muhyiddin İbn Arabi (2009). Hakikat ve Tefekkür, Çev. Mahmut Kanık. Ankara: Hece Yayınları, s. 57.

Özdalga, E. (1998). The Veiling Issue, Official Secularism and Popular Islam in Modern Turkey, Curson Press.

Özdemir, R. (1986). 19. Yüzyılın Illk Yarısında Ankara. Ankara: Kültür ve Turizm Bakanlığı Yayınları, Gazye Mat. San. ve Tic. A.Ș.

Özek, Ç. (1964). Türkiye'de Gerici Akımlar ve Nurculuğun İçüzü̈. İstanbul: Varlık Yayınları.

Özer, İ. (2015). Demokrat Parti Dönemi Siyasi ve Sosyal Hayat. İstanbul: İskenderiye Kitap.

Özekmekçi, M. İ. (2012). Türk Sağında Ayasofya İmgesi, (Der. İ. Ö. Kerestecioğlu ve G. G. Öztan), Türk Sağı, İstanbul: İletişim Yayınları, s. 283-306.

Pitard, P. (1934). Anadolu, (Çev. Reşat N. Nuri), Ankara: Hâkimiyeti Milli Matbaası.

Reed, H. A. (1954). Revival of Islam in Secular Turkey, Middle East Journal, 8(3), 267-282.

Safi, İ. (2005). Türkiye'de Muhafazakârlı̆̆ın Düşünsel-Siyasal Temelleri ve 'Muhafazakâr-Demokrat' Kimlik Arayışları (Yayınlanmamış Doktora Tezi), Ankara Üniversitesi, Sosyal Bilimler Enstitüsü, İstanbul.

Serter, G. (2017). Gencay Serter Fotoğraf Arşivi.

Serter, G. (2018). Muhafazakâr Kentin İnşası. İstanbul: Notabene Yayınları.

Shaw, S. J. (1977). History of the Ottoman Empire and Modern Turkey, Vol:2, United Kingdom: Cambridge University Press.

Söğütlü, İ. (2008). Osmanlı'dan Cumhuriyet'e Türkiye'de modernleşme: Kırılmalar ve süreklilikler. Muhafazakâr Düşünce Dergisi, 5(18), 33-54.

Şen, S. (1995). Refah Partisi’nin Teori ve Pratiği. İstanbul: Sarmal Yayınevi.

Şengül, T. (2009). Kentsel Çelişki ve Siyaset. Ankara: İmge Yayınevi.

Şenyapılı, T. (1981). Gecekondu ‘Çevre’ İşçilerin Mekânı, Orta Doğu Teknik Üniversitesi, Mimarlık Fakültesi Basım İşliği, Ankara.

Tankut, G. (1990). Bir Başkentin Imarı Ankara: (1929-1939). Ankara: ODTÜ Yayınları.

Tekeli, İ. (2001). Modernite Aşılırken Kent Planlaması. Ankara: İmge Kitabevi.

Tekeli, İ. (2009). Cumhuriyet’in Belediyecilik Öyküsü (1923-1990). İstanbul: Tarih Vakfi Yurt Yayınlar1.

Toker, M. (1966). Ísmet Paşa 'yla 10 Yll 1957-1960, (2. Cilt). İstanbul: Akis Yayınları, Ajans-Türk Matbaası.

Yazıcı, N. (1999). Osmanlı Sosyal Hayatında Bir Kesit: Tanzimat Döneminde Mesire. İslami Araştırmalar Dergisi, 12(3-4), 253-258.

Yaşl1, F. (2014). AKP, Cemaat, Sunni-Ulus (Yeni Türkiye Üzerine Tezler). İstanbul: Yordam Kitap.

Yücekök, A. N. (1971). “Türkiye'de Örgütlenmiş Dinin Sosyo-Ekonomik Tabanı (1946-1968)”. Ankara: Siyasal Bilgiler Fakültesi Yayınları, No:323, Sevinç Matbaası, s.133.

Zürcher, E. J. (2011). Modernleşen Türkiye 'nin Tarihi, (Çev. Yasemin Saner). İstanbul: İletişim Yayınları. https://www.google.com.tr, (04.02.2017).

http://haber.sol.org.tr/kent-gundemleri/devlet-ciftliginden-rant-odagina- ataturk-ormanciftligi-haberi-48135, (08.11.2011). 
